NBER WORKING PAPER SERIES

\title{
MICROSTRUCTURE OF THE YEN/DOLLAR FOREIGN EXCHANGE MARKET: PATTERNS OF INTRA-DAY ACTIVITY REVEALED IN THE ELECTRONIC BROKING SYSTEM
}

\author{
Takatoshi Ito \\ Yuko Hashimoto \\ Working Paper 10856 \\ http://www.nber.org/papers/w10856
NATIONAL BUREAU OF ECONOMIC RESEARCH
1050 Massachusetts Avenue
Cambridge, MA 02138
October 2004

The authors are grateful to EBS for their understanding the value of academic research and providing a proprietary data set for the academic purpose with few restrictions and a modest fee. Also, we are grateful to EBS analysts in New York for guidance on the nature of the data. A long-time encouragement from Professor Charles Goodhart has been instrumental in moving forward this line of research. Helpful comments from Bob Rankin (Reserve Bank of Australia) during the preparatory stage were appreciated. We are grateful to Graham Elliott and Rich Lyons for their comments and suggestions on an earlier version of the paper. Comments by Ryan Love on an earlier draft is also helpful. Discussions with foreign exchange dealers in New York and London in the fall of 2003 were also helpful in understanding the structure of the market. The views expressed herein are those of the author(s) and not necessarily those of the National Bureau of Economic Research.

(C2004 by Takatoshi Ito and Yuko Hashimoto. All rights reserved. Short sections of text, not to exceed two paragraphs, may be quoted without explicit permission provided that full credit, including (๑) notice, is given to the source. 
Microstructure of the Yen/Dollar Foreign Exchange Market: Patterns of Intra-day Activity Revealed in the Electronic Broking System

Takatoshi Ito and Yuko Hashimoto

NBER Working Paper No. 10856

October 2004

JEL No. F31, F33, G15

\section{ABSTRACT}

This paper establishes several intra-day patterns of the high-frequency exchange rate behavior, using the firm bid-ask quote, transaction of the EBS data set. First, the activity of quote and transactions is high in the beginning hours of the three major currency markets - Tokyo, London, and New York and low during the Tokyo and London lunch hours and late afternoon in New York. Second, a new observation is obtained in that activity does not increase toward the end of business hours in the three major markets, even during the closing hours of New York on Friday. Third, an average bid-ask spread is narrow (wide), when quote and deal frequencies are high (low, respectively), except the beginning hour of Tokyo (GMT 0), when the bid-ask spread is wide despite high levels of activity.

Takatoshi Ito

Graduate School of Economics

University of Tokyo

7-3-1 Hongo, Bunkyo-ku, Tokyo 113-0033

JAPAN

and NBER

itointokyo@aol.com

Yuko Hashi

Department of Economics

Toyo University

5-28-20 Hakusan, Bunkyo-ku,

Tokyo 112-8606 Japan

yhashi@toyonet.toyo.ac.jp 


\section{Introduction}

This paper describes the intra-day patterns of market activities-frequencies of quote revisions, transactions, and bid-ask spread — of the yen/dollar spot exchange rate using a newly available data. The data, provided by the EBS, consist of global electronic broking bid-ask quotes and transactions for three years starting January 01, 1999 at the frequency of every one second. ${ }^{1}$ This data set has advantage over the frequently-used, indicative quotes of a foreign exchange market tick-by-tick data set, such as FXFX of Reuters, in at least in two important aspects. First, the quotes in the electronic broking are "firm" quotes, in that the banks are committed to trade at those quoted prices. ${ }^{2}$ The firm quotes can be hit, without recourse, for transactions by any counter-party in the system, provided that the counterparty has a credit line with the bid/ask posting institution. In contrast, the indicative quotes of FXFX screen are those input by dealers to give market information without any commitment for trade. The reliability of indicative quotes as a market reality is much less than firm quotes in the electronic broking system. Second, transactions data that are available in the electronic broking system is simply not available in the FXFX screen.

Major findings include the following: (1) Activity-measured by the number of quote entries (price changes) and the number of deals - and bid-ask spreads have a distinct intra-day pattern; (2) Activity is high in the beginning hours of the three major currency markets-Tokyo, London, and New York; (3) There is little evidence that the activity increases toward the end of business hours in the three major markets, even during the closing hours of New York on Fridays, thus there is little evidence of U-shape pattern-this is a new observation; (4) Activity is quite low during the lunch hours of Tokyo and London, late afternoon hours of New York; (5) An average bid-ask spread is narrow (wide), when quote and deal frequencies are high (low, respectively), except the beginning hour of Tokyo (GMT 0), when the bid-ask spread is wide despite high levels of activity.

The contribution of this paper to the literature is three-fold. First, the paper presents a careful description of intra-day activities, using the newly-available data consisting of "firm" quotes and deals, taking into account time zone and daylight saving time of major markets, national holidays, day of the week effect, and other factors. Second, it is found

\footnotetext{
${ }^{1}$ The data set was provided for fee by the EBS Co., for the use at the University of Tokyo, Research Center for the Advanced Science and Technology. The authors are grateful to EBS for such an arrangement.

${ }^{2}$ See Goodhart and O'Hara (1997: p.78) for general discussions on the difference between the indicative and firm quotes.
} 
that in the foreign exchange market, unlike the stock market, there is no U-shape pattern of activities. Third, a negative correlation between the number of deals and the width of bid-ask spread is generally observed during the active time of the day, but the first business hour of Tokyo has wider bid ask spread and higher activities than the following hour.

The rest of this paper is organized as follows: Section 2 explains the basics of the structure of the foreign exchange market, and the role of electronic broking system. The importance of electronic broking system may be far beyond what is commonly believed.

Section 3 describes the data. Section 4 is a main part of this paper, establishing intra-day patterns of activities. Various tests are conducted to establish the patterns revealed in the data. Section 5 concludes the paper.

\section{A rise of the electronic broking system}

\subsection{Global Survey}

The state of the global foreign exchange market is available from a market survey by central banks conducted under coordination of the Bank for International Settlements (BIS(2002)), once every three years. The most recent survey was conducted in April 2001 , and the BIS report was issued in 2002.

According to the survey, in April 2001, the average daily turnovers of the foreign exchange were $\$ 1.2$ trillion, down from $\$ 1.5$ trillion in April 1998. Of these turnovers, spot transactions accounted for $\$ 387$ billion, outright forward $\$ 131$ billion, and swaps $\$ 656$ billion. Decomposing into currency pairs, \$/Euro accounts for $\$ 354$ billion, \$/Yen \$231 billion, \$/GBP \$125 billion. Foreign exchange transactions may be between reporting dealers ( $\$ 689$ billion), between a dealer and other financial institutions ( $\$ 329$ billion), or between a dealer and non-financial customers ( $\$ 156$ billion). Trades could be between local parties ( $\$ 499$ billion), or between cross-border parties ( $\$ 674$ billion)

Trends, revealed from the past surveys (up to 2001), are as follows. (1) Spot trades are on the decline; (2) Swaps are on the rise. (3) trades among reporting dealers fell substantially.

The decline in the spot turnovers (14\% decline form the 1998 survey) is attributed to "the introduction of the euro, the growing share of electronic broking in the spot interbank market, consolidation in the banking industry and international concentration in the corporate sector appear to have been the main factors driving the fall in turnover." (BIS 
(2002; p. 6) In different categorization, the trades between dealers who report to the BIS surveys has declined substantially. ${ }^{3}$ "This can in part be explained by the growing role of electronic brokers in the spot interbank market. The use of electronic brokers implies that foreign exchange dealers generally need to trade less actively among themselves." (BIS (2002; p.7).) This trend means that "hot potatoes" (Lyons (1997)) are less important now, and a cool supercomputer is increasingly important. In other words, dealers' tactics to transform order flows from the corporate sector into the interbank market may be less important than before, and the dealers' behavior in posting firm bids and asks through the electronic broking system is more important then before. ${ }^{4}$ In order to understand the high-frequency movements of the foreign exchange rate, analyzing the electronic broking system is now essential as well as the influence of order flows. (See Lyons $(1996,1998)$ for the view that order flows are important for dealer's strategies.)

Although the importance of electronic broking is pointed out, the number of market shares is not disclosed in the global tabulation. In the Tokyo market survey conducted by the Bank of Japan as a part of the BIS study gives a detailed look at the rise in the electronic trading in the Tokyo market.

Weights of different markets in global turnovers of foreign exchanges by time zone and particular local markets are shown in Table 2-1 and, for the yen/dollar only, in Table 2-2. The Asian region accounts for about $20 \%$ of worldwide all-currency trades and $40 \%$ of worldwide yen/dollar trades, of which Tokyo accounts for about a half of all currencies and three-quarters of yen/dollar trades. The UK and European markets account for about $50 \%$ of global turnovers and $30 \%$ of yen/dollar trades, of which London accounts for two-thirds in all currency or yen/dollar trades. The North American accounts for just short of $20 \%$ in all currency or yen/dollar trades, of which the U.S. has most of the share. Insert Table 1-1 and 1-2

If market shares of electronic spot trading are similar to those of total kinds of foreign exchange turnovers, and if most of trades are done during the currency dealers' business hours (local time 9 to 5), then about 40 percent of global trades are conducted in Tokyo business hours (GMT Hours 0 to 8); 30 percent of them are in conducted in London business hours (GMT Hours 9 to 17, during the standard time; and one hour earlier during

\footnotetext{
${ }^{3}$ However, between 2001 and 2004, there are indications that spot trades of major currencies have increased. See, for example, a summary of such a trend on the EBS home page: http://www.ebs.com/products/spot.asp.

${ }^{4}$ Our interviews (in November 2003) with banks with substantial foreign exchange trading in London reveals that they have reduced in the last few years the degree of discretion of dealers and shifted proprietary trading to the specialized section. Computer models have replaced dealers' instincts.
} 
the daylight saving time); about $20 \%$ of them in the New York business hours (GMT Hours 14 to 22, during the standard time; and one hour earlier during the daylight saving time). This is just a rough estimate of market size, and has some implications to intra-day patterns of the foreign exchange turnovers.

\subsection{Central Bank Survey in Tokyo}

The BIS report (2002) does not have a separate analysis of electronic broking, although it suggests that transactions through electronic broking system have increased and the larger share of electronic broking system contributed to the decline in the spot transactions in the recent years.

The Bank of Japan survey on the Japanese market as a part of the global BIS survey gives a more detailed picture on the importance of electronic broking system. The following statistics are derived from the Bank of Japan (2001).

In the foreign exchange market in Tokyo in April 2001 had 146.8 billion yen of transactions, of which 122.7 billion yen was in the interbank market, and 24.1 billion yen was in the customer market. In the interbank market, transactions are spot trading (27.8 billion yen), forward trading (10.7 billion yen), or swap trading ( 84.2 billion). Of the Spot transactions of 27.8 billion yen, about half (13.4 billion yen) was done via electronic broker, another half (13.0 billion yen) is through direct dealing. The human broker is now diminished to be a minor segment (1.4 billion yen) of the market.

In broker trades in Tokyo, more than 90 percent of broker trades are done through the electronic broking system, as opposed to human brokers. The ratio of electronic trading has grown rapidly in the last several years. The ratio of electronic broking transactions to total spot has increased from $12.0 \%$ (1995) to $36.7 \%$ (1998), to $48.3 \%$ (2001). The ratio of electronic broking transactions to total broking transactions increased from $32.1 \%$ (1995) to $79.3 \%$ (1998) to $91.0 \%$ (2001). By now, the electronic broking system is a dominant form of spot broker transactions, and as important as direct dealing in the overall spot trades.

By currency decomposition, the Tokyo market is skewed toward the dollar/yen transactions. The dollar/yen accounts for $69.2 \%$, Euro/dollar 13.2\%, and Euro/yen, $4.2 \%$.

In summary, the electronic broking system is now dominating in the spot transaction. At least for the yen-dollar market in Tokyo, the voice broker is very much of an endangered 
species, and the electronic broking system is now replacing some of the direct dealings between banks.

\section{The EBS data}

\subsection{EBS electronic broking system}

The EBS has a strong market share (in absolute terms and in comparison to Reuter D-3000) in the yen/dollar rate and the Euro/dollar rate and covers more than $90 \%$ of the yen/dollar trade. ${ }^{5}$ Therefore, it is safe to assume that almost all electronically brokered yen/dollar spot deals are represented in the data set. The EBS is a provider of trading technology, and the quotes and transactions are shown continuously, 24 hours a day. The EBS screen shows the "firm bid" and "firm offer", the bid and offer that are committed to trade if someone on the other side is willing to trade at that price. (For the general reference on the microstructure of the foreign exchange market, see Goodhart and O'Hara (1997), Lyons (1995) and Lyons (2001).)

The EBS system facilitates, as part of the dealing rules, each institution to control bilateral credit lines. Namely, each EBS-linked institution sets credit lines (including zero) against all other potential counter-parties. Therefore, an institution faces a restriction of bid, offer, or deal from other institutions. When bid and offer rates are posted for the system, they are not necessarily available to all participants of the EBS system. The EBS-registered trader's screen shows the best bid and best offer of the market and best bid and best offer for that particular institution. In normal times, the best bid of the market is lower than the best offer of the market. Otherwise, some institution that has positive credit lines with both institutions on the bid and ask sides will be able to make profits by arbitrage.

As part of facilitating an orderly market, EBS requires any newly linked institution to secure a sufficient number of other banks that are willing to open credit lines with the new comer. A smaller or regional bank may have fewer trading relationships, thus not as many credit relationships. Then the best bid and ask for that institution may be different from the best bid and ask of the market. A smaller or regional bank may post more aggressive prices (higher bids or lower asks) because they will have relatively fewer credit relationships, implying that they will see fewer dealable prices generally.

\subsection{The EBS Data Set}

${ }^{5}$ Goodhart, Ito and Payne (1996) and Goodhart and Payne (1996) have used the data obtained from Reuter D2000-2 that is predecessor of D3000. 
The EBS has made available a high-frequency (one-second slice) data set that contains information of, among others, best bid, best ask, deals done on the bid side and deals done on the ask side. ${ }^{6}$ Moreover, the EBS deal history shows whether the deal is done on the bid side (the bid was taken) or the ask side. The EBS data set does not contain information on the volume of transactions associated with bid, offer, or deal.

The Data prepared by EBS and purchased by the University of Tokyo contains the following data.

-Currencies: (a) the yen/dollar rate; (b) the dollar/euro rate.

-Period: From 01 January 1999 to 31 December 2001.

-Frequency: Originally, tick-by-tick, sliced to every second. ${ }^{7}$

-Items: (a) Best bid of the market; (b) Best offer of the market; (c) Deal rate done on the bid side, or lowest selling price ("the lowest given"); (d) Deal rate done on the offer side, or highest buying price ("the highest paid"). ${ }^{8}$

The basic characteristics of the full sample of raw (original) as well as filtered data used in this study are shown in Table 2. "The number of price changes" means the number of quote changes on either side of the bid-ask quotes or both at the same time. ${ }^{9}$ Then, the difference between "the number of price changes" and the sum of "the number of price changes on the bid side" and "that on the ask side" is the number of quote changes on both sides simultaneously.

\section{Insert Table 2}

The best ask price (in the yen/dollar unit) is almost always higher than the best bid price. But there are a small number of reversals (that is, the best bid being higher than the ask

\footnotetext{
${ }^{6}$ The data set is a proprietary data set of EBS. The usage is restricted to those who are affiliated in the Research Center for Advanced Science and Technology, the University of Tokyo.

${ }^{7}$ Data are of the 1-second time slice. The system records, at every second, bid, offer, deals that are posted and carried out in the world-wide EBS system. Bid and offer rates are recorded at the end of time slice. For example, bid and offer rate at xx hour, yy minute, $\mathrm{zz}$ second. Fluctuations of the bid and offer rates within the second (in the time slice) are not recorded and cannot be inferred. It is theoretically possible that bid and offer rates move up and down within the second, but not shown in the data set. Deal rates are recorded on the basis of Highest Paid and Lowest Given in the 1-second time slice.

${ }^{8}$ The deal (on either side) recorded at zz second includes those that took place between zz-1 second to zz second. When there are multiple trades within one second, "lowest given price" and "highest paid price" will be shown. A highest paid deal means the highest price hit (done) on the ask side within one second and the lowest given deal means the lowest price hit (done) on the bid side within one second.

${ }^{9}$ Price changes could be generated by new entries of quotes, withdrawal of former quotes or disappearance of the quote due to "hits".
} 
price $^{10}$. Among 8.5 million quote entries, 72,429 entries (less than $1 \%$ of the time) have shown reversals---inverted bid-ask spread. We believe that such a reversal happens for the following reason. It occurs due to the (lack of) credit lines. If a bank that posts the bid and another bank that posts the ask do not have a credit line each other, and no other bank has credit lines to both banks that post the quotes, then the inverted spread, but not implying an arbitrage opportunity, may occur. We decided to remove the inverted spread entries because it is infrequent, and difficult to interpret from financial economics, although it is a normal situation from the system design.

Among the total number of deals done on each of bid and ask side, there were 24,119 reversal of deals - the deal on the ask side is lower than the deal on the bid side, on the yen/dollar unit. This may happen for several reasons. Recorded deals are "lowest given" and "highest paid" during the time slice ( 1 second). First, the firm ask and firm bid may move around during the one second, having "hits" many times so that the reversal may happen. Second, under the credit-screened market, different market participants may see the different prices during the very short time intervals. Third, deals are published when they are completed. Since communication between the terminal and server takes milliseconds a recorded deal may have begun at a previous time-slice.

\section{Figure 1}

Figure 1 shows illustration of price changes and transactions with negative spread. The solid line and dashed line indicate the price changes with ask and bid quote, respectively, and $\circ$ and $\square$ shows the deals on ask and bid side, respectively.

\section{A First Look at the Intra-day Patterns}

\subsection{Definition of Activity during the day}

In the following, the market activity and bid-ask spread for a standardized time aggregation (one hour) are examined. As market activity, we will take the number of price changes and the number of deals (the sum of bid-side deals and ask-side deals) will be counted for each time interval. ${ }^{11}$ Also the average bid-ask spread for the period is

\footnotetext{
${ }^{10}$ In some situations, different third parties see the bid or ask. The price seen by a third party may represent a very aggressive bid or ask, but not an arbitrage price. A single third party may see both prices. In such situations, they may see an arbitrage opportunity, but there is no guarantee that they can execute deals at both prices. It is a matter of timing and such prices are likely to be short lived. ${ }^{11}$ Note that the number of price changes and the number of deals in the data set may not be exactly match the total number of price changes and deals in the EBS system, because the data set is in terms of the one-second slice. If there are more price changes and deals within one second, the recorded
} 
calculated.

The intraday patterns have been explored in many papers before. However, except for Goodhart, Ito, and Payne (1996) and Goodhart and Payne (1996), all papers use indicative prices. Moreover, the period is typically for several months. This paper establishes the facts with firm quotes and deals, that are far better in describing the market than indicative prices. Intraday patterns using indicative prices have been shown by, for example, Andersen and Bollerslev (1997, 1998), Baillie and Bollerslev (1990),

A higher level of activity means a larger number of price changes, and a larger number of deals. This is due to the fact that the number of price changes by dealers tends to increase when more participants are in the market; when more news become available; when the most competitive participant (who post best bid and ask) is reacting to news and market develops quickly; and when the bids and asks are hit more often (so that the best bids or asks are knocked out). The number of deals tends to increase when more participants with heterogeneous expectations are present in the market; and when more news that can be interpreted differently, become available.

As to the bid-ask spread, it tends to become narrower when more participants are in the market (that is, market is deep) and when expectations are relatively homogeneous.

\subsection{Standard Time and Daylight Saving Time}

In this section, intra-day activity is described by the time-aggregation of one hour data. Activity is represented as the number of seconds where price changes are recorded and the number seconds where deals are recorded. The average bid-ask spread of the hour also represents the market depth. These indicators of market activity are calculated for each GMT Hour (Hour 0 to 23), and then averaged over a certain period (for one year, or a particular day of the week).

Since daylight saving time is adopted in London (from the last Sunday of March to the last Sunday of October) and New York (from the first Sunday of April to the last Sunday of October), the GMT hour does not correspond to local business hour between the summer and the winter. Thus, aggregation for the year is divided into the two periods: ${ }^{12}$

\footnotetext{
numbers are less than the true numbers.

${ }^{12}$ Daylight saving time in 1999 was from April 4 to October 31 in the United States; from March 28 to October 31 in the United Kingdom; in 2000, from April 2 to October 29 in the United States, and from March 26 to October 29 in the United Kingdom; and in 2001, from April 1 to October 28 in the United States and from March 25 to October 28 in the United Kingdom.
} 
Daylight Saving (Summer) Time: First Sunday of April-last Sunday of October, and Standard (Winter) Time: January-last Sunday of March, the next working day of the last Sunday of October-December.

Note that we eliminate the one-week period when Europe is under the Summer Time but the US is not. Figures 1-1 to 1-6 show the intraday (Hour $0-23$ ) pattern of the activity and the bid-ask spread, excluding Saturdays, Sundays, and national holidays in the three markets

Figure 2-1: Summer 1999

Figure 2-2: Summer 2000

Figure 2-3: Summer 2001

Figure 2-4: Winter 1999

Figure 2-5: Winter 2000

Figure 2-6: Winter 2001

Findings are summarized as follows:

(1) There is high correlation between the "number of price changes" and the "number of deals".

(2) There are three peaks in a day for the number of price changes and the number of deals. In Summer, peaks of the activity are seen at Hour 0, Hour 6-7 and Hour 12-14; and in winter, Hour 0, Hour 8, Hour13-15.

(3) There are three troughs in a day. In Summer: Hour 3; Hour 10-11; and Hour 21: and in Winter, Hour3, Hour 11, and Hour 22.

(4) The three peaks and three troughs produce the U-shape patterns twice a day. The hours when the market activity is at its peak correspond to the Tokyo market opening, London market opening and New York market opening, respectively. On the other hand, the three troughs in a day correspond to the Tokyo lunch hour, London lunch hour, and the evening in New York, respectively. High activity in hour 6-8 may be those in ending hours of Tokyo or beginning hours in Europe; and surging activity in hour 12-14 may be those in ending hours of London or beginning hours in New York.

(5) In general, there is negative correlation between the bid-ask spread and the number of deals (or price changes): The three troughs of the number of deals (or price changes) corresponds to three peaks of the bid-ask spread. One deviation is the Hour 0, when the bid-ask spread is higher than other business hours in Tokyo (except lunch hour) but the number of deals (or price changes) is at the one of the peaks; that is, unlike other times, a positive correlation. 


\subsection{Tokyo, London, and New York effects}

The difference of intraday patterns between the winter and summer helps us to examine the "shape" of each of the three major markets. Figures 1-1 to 1-6 suggest that intraday patterns (in terms of GMT) shift with summer times of London (Europe) and New York. There is no summer time in Tokyo. When London and New York are adopting daylight saving (summer) time, the second and third peaks of the day shift forward by one hour.

But Tokyo closing is only slightly overlapped with London, and London afternoon is overlapped with New York morning. U-shape of Tokyo and London is not quite directly testable. However, whether the U-shape is to be believed, the shift of business hours (in terms of GMT) in the summer in London gives a clue to a question whether the surge in Hours 7-8 are due to Tokyo closing or London opening.

From figures above, it is immediately clear that the peak of activity shifts by one hour in GMT when London is adopting the daylight saving (summer) time, from Hour 8 in winter to Hour 7 in summer. Since activity in the afternoon and market-ending hours of Tokyo market does not change in terms of GMT hours, the shift of peak at must be due to the shift between the summer and winter time of London/Europe markets' opening. This strongly indicates that the surge is more due to London opening than Tokyo closing.

A trough at Hour 3 corresponds to the lunch break in Tokyo. Historically, the interbank foreign exchange transactions had a lunch break (regulatory shutdown) during the lunch hours. When the regulation was removed, the activities during the lunch hour increased at the expense of those before and after, the net effect was higher. ${ }^{13}$ A trough at Hour 11 in the winter and Hour 10-11 corresponds to lunch hours in Europe, although it seems a little bit early for lunch in London. The activity declines sharply in the afternoon hours in New York, showing no surge toward the end of NY business hours. There is an increase in the activity from Hour 17 to Hour 18 in the summer, but the change is very small.

In order to identify statistically the "shape" of the intra-day pattern, we calculated standard deviations for each of indicators of market activity-the number of price changes, number of deals and spread - which are also plotted along with indicators in the figures above. As is clear from the figures above, the standard deviations (dashed lines) of each indicator of market activity is very small. We also conducted the T-test for difference between two GMT hours for the number of price changes, number of deals and

${ }^{13}$ See Ito, Lyons, and Melvin (1998) for such a phenomenon. 
the spread. The test was conducted for every pair of different GMT time so that to identify the different levels of activity at various times of the day. In the table below, we show the test results of two adjacent hours to save space. The time of the day effects is statistically tested in section 6.

The number of price changes and the number of deals done is found to be statistically different for every two-adjacent-hour pair except hours 7 and 8, hours 10 and 11, hours 13 and 14, and hours 21 and 22. These identical hours correspond to the London and European markets' opening (GMT 7-8), before and after the lunch time (GMT 10-11 and 13-14), and between the New York market's closing and the Asia-Pacific market's opening. The test statistics show the distinct pattern of the beginning of Tokyo market at Hour 0 and the Tokyo lunch time at Hour 3. On the whole, the number of price changes and the number of deals have recognizable time-to-time patterns.

Although the intraday pattern of the bid-ask spread is less obvious than the number of price changes and deals, we still find some patterns: the spread stays relatively narrow for the first half of the day, then becomes wider as the market becomes relatively calm in the New York afternoon, and becomes the highest during the several hours between the New York market's closing and the Asia-Pacific market's opening.

\section{Insert Table 3}

Table 3 shows the t-test for hour-to-hour differences of the price change frequencies, deals frequency, and the width of bid-ask spreads. The test shows whether the characteristics of activity or bid-ask spread of hour $t$ is different from that of hour $t+1$.

From our study with firm bid-ask quote data, we derive two major findings of activity patterns during the day. First, there is no evidence for a U-shape activity pattern for a major market, contrary to the common belief in the literature. ${ }^{14}$ There is a surge of activity in the opening hours of the three major markets, but no surge toward the end of each market. This is the new insight in the literature.

Second, the activity is at its highest during the opening hours of New York (overlapped with the afternoon of London) and lowest during the late afternoon hours of New York, before the Tokyo market opens, with significant drops during the lunch hours of Tokyo

\footnotetext{
${ }^{14}$ For the empirical test and survey of the U-Shape pattern in financial markets, see, for example, Harris (1986), Foster and Viswanathan, (1993), Ito, Lyons and Melvin (1998), Andersen and Bollerslev (1998).
} 
and London. These salient features have been well-known in the literature using indicative quotes. Here they are confirmed with better data sets with deal counts as well as firm quotes.

\subsection{Adjusted GMT}

If we used the GMT 24 hour clock (Hour 0-23) for the entire year, then the same GMT hours mix different business hours in London and NY local hours depending on the summer and winter. This is inappropriate when we investigate intraday pattern of activities, in particular, the beginning hours and ending hours of major markets

With these observations, the summer/winter adjusted intraday pattern is created with the following rule: ${ }^{15}$ For adjusted GMT clock, the hours during the summer will be pushed back by one hour for London and US business hours, so that a GMT hour corresponds to the same local business hour (say, London local time 9am), regardless of summer or winter. Essentially, this amounts to matching the peak of the activities for the beginning hours of London and New York. There are some technical difficulties to do this. First, the beginning hours may not be clear cut. It could be $9 \mathrm{am}$, or $8 \mathrm{am}$, or even $7 \mathrm{am}$, depending on their business practices of the city.

Adjusted GMT is created with the following procedures:

(1) Adjusted GMT Hours 0-5 are the common to winter and summer, and they correspond to original GMT data. This is because there is no summer time in Japan.

(2) Adjusted GMT Hour 6 consists of original GMT Hour 6 of the winter time only. It contains no summer time observations. ${ }^{16}$ This adjustment is made to allow business-hour local time of London and New York will be matched regardless of the season in the adjusted GMT clock.

(3) Adjusted GMT Hour $7-22$ are constructed as follows. Adjusted GMT Hour 7 is original GMT Hour 7 of the winter time and Hour 8 of the summer time. Beginning GMT 7, the local time for London and New York will be the same regardless the season. This corresponds to an assumption that a surge of opening hours starts at $7 \mathrm{am}$

\footnotetext{
${ }^{15}$ One may think that all observations can be shifted by one hour during the summer time, but that is not appropriate, since Tokyo does not have daylight saving time. The adjustment is to preserve the Tokyo business hours as GMT hours, while London and NY business hours are adjusted by one hour for their shift during the summer in terms of GMT hours. Shifting only London-based or NY-based quotes and deals would be another solution, but it is not possible since bank names of quotes or deals are not available.

${ }^{16}$ This adjustment is needed to bridge from the end of Tokyo time to the beginning of the European time. Possibilities of another breaking point like Hour 7 or Hour 8 were tried. Not much difference is detected, except alignment of the peak of activities seems to be best when the break is between Hours 6 and 7.
} 
in London and 8 am in the Continental markets. Then Adjusted-GMT Hour $\mathrm{x}$ is GMT Hour $x$ of the winter time and GMT Hour $x+1$ in the summer time, for $x=7$ to 23 .

(4) Adjusted GMT Hour 23 consists of original GMT Hour 22 of the summer time only. No winter observations.

(5) Adjusted GMT Hour 24 consists of original GMT Hour 23 of both the summer and winter time. This assumes that in Tokyo, activities in Hour 8 am is common for the summer and winter. This is a reasonable assumption because there is no summer time in Japan.

Insert Table 4-2

The adjusted GMT time line is shown in Table 4-2. According to the adjusted GMT, the peaks of activities during the day - that correspond to opening hours of Tokyo, London, and New York-occur at the same hours.

Figure 3-1, Figure 3-2, Figure 3-3

With these understandings, the intraday pattern adjusted for the summer/winter time in 25 hour clock (adjusted GMT) is as follows. All figures are excluding observations on Saturday, Sunday, National holidays in Tokyo, London, or New York. Not much difference in the intra-day patterns are observed among the three years.

\section{The Day of the Week Effects}

With the adjusted GMT clock, the day-of-the-week effects can be analyzed with parsimonious way (Monday pattern; instead of Monday in the summer and Monday in the winter). There are two interesting questions that can be answered using the day of the week: First, whether the opening hours in Tokyo on Mondays is significantly different from other hours; and, second, whether the closing hours in New York on Friday is significantly different from other hours. ${ }^{17}$

If orders accumulated during the weekend (about 35 hours) is much larger than those accumulated during the overnight gap (2-3 hours) between New York close and Tokyo open, then the first hour of Tokyo on Monday (Hour 0 in adjusted GMT) may be quite different, most likely much higher activity, from that hour on any other day of the week. Similarly, if weekend deprives investors from opportunities of rebalancing portfolio for

${ }^{17}$ The day of the week effects in stock markets is commonly observed and analyzed. 
many hours, then investors may have to square positions before a weekend. Then the activity in the closing hours in New York (Hours 17-18 in adjusted GMT) on Friday may be much higher than those on any other days of the week. Followings provide the intra-day pattern of the day of the week averaged over the year 2001. In order to save space, figures for other years are omitted.

Figure 4-1: Monday, 2001,

Figure 4-2: Tuesday, 2001,

Figure 4-3: Wednesday, 2001,

Figure 4-4: Thursday, 2001,

Figure 4-5: Friday, 2001

Overall, the pattern of the activities of each day does not show a large deviation from the intra-day pattern of the year 2001. The number of price changes and deals at Hour 0 does not seem to have neither the Monday effect nor the Monday opening effect. The intra-day pattern of spread of Monday morning does not seem to differ from other days of the week.

Since the intra-day pattern of Hour 0 is not clearly found specific to Monday morning, we explicitly focuses on the activities during Monday Hour 0. The figures from 4-1 to 4-3 show the yearly average number of price changes, deals, and bid-ask spread in 5 minutes intervals during the Hour 0 on Mondays. Overall, the number of price changes and the number of deals for the first 5 minutes are as high as that for the last 5 minutes, whereas the bid-ask spread for the first 5 minutes is higher than the last 5 minute by 0.005 . Both of the number of quote (deal) entries and the spread continue to decrease for the first half hour. The recovery to the "normal" activity pattern - the higher the price changes (deals), the narrower the spread—emerges about 40 minutes after the Tokyo market opens.

$$
\text { Figures 5-1, 5-2, 5-3 }
$$

From the careful examination on intra-day pattern of activity across the week, following findings became obvious.

(1) No special Monday opening effect-Hour 0 on Monday-in the market activity is observed.

(2) It is commonly seen on any day of the week that Hour 0 is special in that the numbers of quote and deal entries are high, whereas the bid-ask spread is not narrow. In other hours, the correlation is negative between the bid-ask spread and the number of deals (or quotes). 
(3) There is no activity surge in the afternoon of New York, despite the weekend. If any, New Yorkers go home early on Fridays.

(4) The activity surge in Hour 23 and 24 on Monday-Thursday is due to Sydney markets and early Tokyo markets. There is no activity on Saturday morning in these markets. That is, there is virtually no activity in the market of Hour 23 and 24 on Friday.

\section{Relationship between the number of price changes, deals, and spread}

It is theoretically expected that the number of price changes and the number of deals are positively correlated. This is because when the number of quote entries by market participants is large, then the possibility of deals done must be large. A simple regression shows that when the price changes are frequent, the deals are frequent. The relationship between the number of deals and the number of price changes is shown in Table 5-1.

\section{Insert Table 5-1}

It is also expected that the bid-ask spread is negatively correlated with either of the first two measures. When the bid-ask spread is narrow, then the difference between the buy side and sell side is small, so that even with a slight change in opinion results in a deal. The reverse explanation is also possible. When the market is deep (more participants are present and ready to trade at similar prices), then even with many frequent deals, the bid-ask spread stays narrow. However, there may be an exception to this relationship. When the Tokyo market opens after a long break, such as a weekend, the bid-ask spread may be wider as market participants are unsure about the market conditions and other participants' positions, while the numbers of deals and quote revisions may be higher, as some participants have to carry out some accumulated orders from customers quickly.

Let us test a hypothesis that the opening hour of the Tokyo market has special characteristics, because it follows a few hours of extremely low activity. The bid-ask spread and the number of price changes has a stable relationship throughout the day, except for the first business hour of the Tokyo market. Then we run a regression model as follows:

$$
\text { spread }=\text { constant }+(\alpha+D 1)^{*} \text { number of price changes }(\text { deals }) \text {, }
$$

where $\alpha$ is expected to be negative and D1 is a hour 0 dummy, taking the value 1 when the quote is recorded in the period of Hour 0 (Tokyo 9am) and 0 otherwise. 
Insert Table 5-2

Estimation results are shown in Table 5-2. Regressions are run for each of the three years, and using the number of price changes (Panel A) or the number of deals (Panel B). As shown in the tables, the statistically significant and negative $\alpha$, as expected, is found. The estimated coefficient of Hour 0 dummy is either significantly negative or insignificant. Therefore, the hypothesis of a special first hour effect, a positive correlation between the spread and activities-namely, the Tokyo opening effect, is not supported by the regressions.

\section{Monday opening effects}

Not only the Hour 0 effect is found to be statistically insignificant in the market activity, but, from the figures from 3-1 to 3-5, the intra-day pattern of Monday opening does not seem to be significantly different from that of opening hours of other days of the week. Here, we statistically test the effect of Monday morning on the market using the Monday Hour 0 dummy to be significant in the following regression model:

spread $=$ constant $+(\alpha+$ Monday Hour 0 dummy $) *$ number of price changes (deals),

where $\alpha$ is expected to be negative and Monday Hour 0 dummy takes 1 when the price changes (deals) is put in at Monday Hour 0 and 0 otherwise.

\section{Insert Table 5-3}

Regression results are shown in Table 5-3. The estimation result on price changes, shown in Panel A, does not support the hypothesis of Monday morning effect in the FX market. The Monday H0 dummy is not significantly positive for the full sample, 1999 and 2000 regressions. In 2001, the coefficient is estimated positive (not significant). The results suggest that there is no Monday opening effect on spread.

The result on the number of deals, in Panel B, is slightly different from the price change result. The Monday Hour 0 dummy is estimated to be positive in the full sample (at $5 \%$ significance level) and in 2000 (at 10\%). The Monday morning effect is found in deal activities, suggesting that the market participants carry out some accumulated orders over the weekend in the first hour of the week, the Monday Tokyo morning at Hour 0, despite the wider bid-ask spread.

\section{$\underline{\text { London and New York effects }}$}


Finally, three hypotheses will be examined, using the time aggregation of one hour. As observed above, we find several features on intra-day patterns such as that the London opening and New York market effects are seen from the shift between the winter time and daytime saving time and that no Monday morning effects is found in the FX market from the day-of-the-week examination. Tokyo opening effect (Hour 0) is (seemingly) insignificant, which is partly because of the pattern of activity specific to Hour 0 . In the following, three hypotheses on the intraday pattern of activity will be statistically tested using various dummy variables. The hypotheses to be examined are:

(H1) The bid-ask spread is narrower (wider) when the activity is high (low, respectively);

(H2) During opening hours of the major markets (Tokyo, London/Europe, New York), activity is higher;

(H3) Toward the close of the major markets, activity is higher.

The combination of hypotheses (H2) and (H3) amount to the U-shape activities. ${ }^{18}$ We test above hypotheses using one of the following two specifications:

$$
\begin{aligned}
& \text { number of price changes }=\beta^{*} \mathrm{D} 1+\gamma^{*} \mathrm{D} 2+\varepsilon, \\
& \text { spread }=\beta^{*} \mathrm{D} 1+\gamma^{*} \mathrm{D} 2+\varepsilon,
\end{aligned}
$$

where D1 are dummy variables representing Hour 0 to Hour 22 to control time of the day effects, and D2 consists of 3 types of dummy variables; London open, London lunch, and NY open. In running regressions, opening hours of three major markets is considered along with the London lunch time.

$$
\text { LDN open } 1=\left\{\begin{array}{l}
\text { at Hour } 7 \text { in summer } \\
1 \text { at Hour } 8 \text { in winter } \\
\text { Otherwise, }
\end{array}\right.
$$

Since $d y / d D 2=\gamma(\mathrm{y}=$ number of price changes or spread $)$ is independent from other explanatory variables, it simply depicts the effect of London opening (London lunch, NY opening) over and above $k$ hours after the Tokyo opens regardless of the daylight saving time. ${ }^{19}$ In case of London opening dummy above, $\mathrm{k}=7$.

18 The U-shape pattern was originally documented for the stock market. In the exchange market, see Hsieh and Kleidon (1996), Ito, Lyons, and Melvin (1998).

${ }^{19}$ The test is conducted including three other sets of dummies: London opening(version 2) $=1$ at Hour 6 in summer, 1 at Hour 7 in winter, and 0 otherwise; NY open (version 2)= 1 at Hour 14 in summer, 1 at Hour 15 in winter, and 0 otherwise; NY open (version 3)= 1 at Hour 13 in summer, 1 at Hour 14 in winter, and 0 otherwise. The results is not reported save space, but it is found that each of the London opening, London lunch, and NY opening has a significant effect on both price changes and spread, and 
Since a large jump of quote entries between hour 5 and hour 6 in summer (which corresponds to the London 5 and 6 hour in the morning) and between hour 6 and hour 7 in winter is in some cases found in figures 2-1 to 4-5, we consider the case London market opens at Hour 6 in summer and Hour 7 in winter.

LDN open $2=\left\{\begin{array}{l}\text { at Hour } 6 \text { in summer } \\ 1 \text { at Hour } 7 \text { in winter } \\ \text { otherwise, }\end{array}\right.$

The London lunch dummy is as follows:

LDN lunch $=\left\{\begin{array}{l}1 \text { at Hour } 10 \text { in summer } \\ 1 \text { at Hour } 11 \text { in winter } \\ \text { otherwise, }\end{array}\right.$

We consider three types of the New York opening dummies as follows:

$$
\begin{aligned}
& \text { NY open } 1=\left\{\begin{array}{l}
\text { at Hour } 14 \text { in summer } \\
1 \text { at Hour } 15 \text { in winter } \\
\text { otherwise, }
\end{array}\right. \\
& \text { NY open } 2=\left\{\begin{array}{l}
\text { at Hour } 13 \text { in summer } \\
1 \text { at Hour } 14 \text { in winter } \\
\text { otherwise, }
\end{array}\right. \\
& \text { NY open } 3=\left\{\begin{array}{l}
\text { at Hour } 12 \text { in summer } \\
1 \text { at Hour } 13 \text { in winter } \\
\end{array}\right.
\end{aligned}
$$

Insert Table 5-4

Regression results are shown in Table 5-4. The regression result of Number of Price Changes on Dummy is shown in Panel A. The results generally show that the dummy variables are significant in most of the time. The Hour 3, Hour 19 and Hour 20 dummies are not significant in some regressions, indicating that the number of quote entries in

that the opening (lunch) hours significantly shifts with the daylight saving time. 
these 3 hours is not significantly different from average entries. Needless to say, these three hours correspond to Tokyo lunch hour and two hours in the New York late afternoon. The results imply that the quote entry does not significantly vary even during the most inactive hours. The London open dummies, London lunch dummy, and New York open dummies are all significant indicating that the market becomes active (shows many price entities on the screen) exactly $k$ hours after the Tokyo market opens-these are the London opening and New York opening effects.

Panel B shows the regression result of the spread on dummy variables. Estimation results show that the dummy variables are insignificant from Hour 10 to Hour 15 in most of the regressions. These hours correspond to the dusk to late evening hours in the Tokyo time, or from morning to early afternoon hours in the London time, and the early morning hours in the New York time. The London open and New York open dummies are not significant in some cases. London lunch hour is insignificant in the regression of 1999, indicating that in 1999 the London lunch time effect was not clearly seen whereas it became clear in 2000 and 2001. As to the London open effect, both types of London open dummies are insignificant in 2000 and 2001, indicating that the London open hour effect is not clearly seen in the width of spread in 2000 and 2001. Finally, type 1 of New York open dummy is insignificant in 2000 and all types of the New York open dummies are insignificant in 2001. These results show us that, as to the spread, we do not tell exactly when the London and New York market opens in 2000 and 2001. The width of spread is not significantly different from other hours even during the opening hours of London and New York.

Both the lack of the latter upswing of the U-shape in activities and the insignificant market open effects in London and New York in terms of bid-ask spread may be due to the recent widespread use of the EBS system. The U-shape is often thought of as coming from inventory control at the end of the business hours in the market, but the EBS has made the inventory control much easier-by making it possible and easier to find market rates and counterparties in other regions of the world regardless of the local hours. This may have contributed to the disappearance of the pick up of the activities toward the end of regular business hours, and little changes of the bid-ask spread during the business hours from Tokyo, London, and New York. ${ }^{20}$ However, the Tokyo market open effect on the bid-ask spread as well as activities is still found significant because the FX trading during the preceding two hours before the Tokyo market opens is extremely thin.

${ }^{20}$ We thank Rich Lyons for his suggestion of this interpretation. 


\section{Conclusion}

In this paper, the intra-daily patterns were investigated from the rich data set of EBS quotes and deals. Some of the findings are well-known such as the high activities at the opening of the market, high correlations between quote entries and deals, and higher activities associated with narrow spreads. However, some of the findings are somewhat surprising. The following observations are new in the literature.

First, there is no U-shape intraday activity pattern in the yen/dollar market. The activities are high during the opening hours but not ending hours. We base this judgment on several observations. Careful observations on the peak of activities, exploiting the difference between Tokyo and London in adoption of summer (daylight saving) and winter time to conclude where the activities originate during the overlapping business hours. There is no surge in activities toward the end of the New York afternoon hours. Even on Fridays, there is no pick up in activities in the NY afternoon hours.

Second, intra-day patterns of activities and bid-ask spreads are quite stable over the time (yearly comparison), or over the week (day-of-the-week comparisons). Namely, the peak of activities is observed in the opening hours (9am in Tokyo; 8am in Europe/7am London, and 8-10am New York), and the troughs are late afternoon hours of New York, with significant drops during the lunch hours in Tokyo and, to the lesser extent, in European lunch hours. The regression shows that the effect of market opening in London and New York on the bid-ask spread is insignificant in 2000 and 2001: that is, the width of spread is insignificantly different from the average even at the opening hours of these two markets. We still find, however, the significantly different and large spread during the Tokyo market open hour.

Third, the bid-ask spread is generally negatively correlated with the indicator of activities: Higher activities are associated with narrow spreads and low activities are associated with wide spreads. However, the first hour, or to be more specific the first half hour of the Tokyo market (GMT Hour 0) has a slightly wider spread than other hours of comparable activities.

Although we have found several interesting facts in the newly available data, there are many tasks left for future research. First, changes in the exchange rate and an activity indicator may be correlated. If the deal is done on one side only, then the exchange rate may move toward that direction. The price impact of deals will be investigated in the future. Second, macroeconomic announcements are often planned during the hour that are before the market opening (say, 8:45 am). However, other markets are open in the 
case of foreign exchange markets. Additional activities on the day of announcements may be detected not in the market (say, NY) where it is announced but in other markets (say, London). 
References:

Andersen, Torben G. and Tim Bollerslev (1997). "Intraday Periodicity and Volatility Persistence in Financial Markets," Journal of Empirical Finance, vol. 4: 115-158.

Andersen, Torben G. and Tim Bollerslev (1998). "Deutsche Mark-Dollar Volatility: Intraday Activity Patterns, Macroeconomic Announcements, and Longer Run Dependencies,” Journal of Finance, Vol. 53, Issue 1, February: 219-265.

Baillie, Richard T. and Tim Bollerslev (1990). "Intra-Day and Inter-Market Volatility in Foreign Exchange Rates,” Review of Economic Studies, vol. 58: 565-585.

Bank of International Settlements (BIS) (2002). Triennial Central Bank Survey 2001 Triennial Central Bank Survey of Foreign Exchange and Derivatives Market Activity 2001 - Final Results, Basle: Bank of International Settlements, March 18, 2002.

[http://www.bis.org/publ/rpfx02.htm\#pgtop]

Bank of Japan (2001). Central Bank Survey of Foreign Exchange and Derivatives Market Activity in April 2001: Turnover Data, Japan, Tokyo: Bank of Japan, October 10, 2001. [http://www.boj.or.jp/en/ronbun/ronbun_f.htm]

Foster, F. Douglas, and S. Vish Viswanathan, (1993). "Variations in Trading Volume, Return Volatility, and Trading Costs: Evidence on Recent Price Formation Models," Journal of Finance 48, 187-211.

Goodhart, Charles; Takatoshi Ito; and Richard Payne, (1996) "One Day in June 1993: A Study of the Working of the Reuters 2000-2 Electronic Foreign Exchange Trading System," in J. A. Frankel, G. Galli, and A. Giovannini (eds.) The Microstructure of Foreign Exchange Markets, Chicago: The University of Chicago Press: 107-179.

Goodhart, Charles and Richard Payne, (1996) "Microstructural Dynamics in a Foreign Exchange Electronic Broking System" Journal of International Money and Finance, vol. 15, no. 6: 829-852.

Goodhart, Charles, A.E. and Maureen O'Hara, (1997). "High Frequency Data in Financial Markets: Issues and Applications" Journal of Empirical Finance, vol. 4: 73-114. 
Harris, Larry (1986). “A Transaction Data Survey of Weekly and Intraday Patterns in Stock Returns,“ Journal of Financial Economics, Vol.16, 99-117.

Hsieh, David A. and Allan W. Kleidon, (1996). "Bid-Ask Spreads in Foreign Exchange Markets: Implications for Models of Asymmetric Information" in J. A. Frankel, G. Galli, and A. Giovannini (eds.) The Microstructure of Foreign Exchange Markets, Chicago: The University of Chicago Press: 41-67.

Ito, Takatoshi, Richard K. Lyons, and Michael T. Melvin, (1998). "Is There Private Information in the FX Market? The Tokyo Experiment" The Journal of Finance, vol. LIII, no. 3, June: 1111-1130.

Lyons, Richard (1995). "Tests of Microstructural Hypotheses in the Foreign Exchange Market," Journal of Financial Economics, vol. 39: 321-351.

Lyons, Richard (1996). "Foreign Exchange Volume: Sound and Fury Signifying Nothing?" in J. A. Frankel, G. Galli, and A. Giovannini (eds.) The Microstructure of Foreign Exchange Markets, Chicago: The University of Chicago Press: 183-205.

Lyons, Richard (1997). "A simultaneous trade model of the foreign exchange hot potato". Journal of International Economics 42, 275-2

Lyons, Richard (1998). "Profits and Position Control: A Week of FX dealing" Journal of International Money and Finance, vol. 17: 97-115.

Lyons, Richard (2001). The Microstructure Approach to Exchange Rates, Cambridge: MIT Press.

Wood, Robert, Thomas McInish, and Keith Ord (1985). "An Investigation of Transaction data on NYSE Stocks," Journal of Finance, Vol.40, 723-741. 


\section{The Data Cleaning}

Examining the raw EBS data, some irregularities were found.

(1) [Negative bid-offer spread] The bid and offer levels are reversed (i.e., negative spread).

Comments: This does not make sense (if the time slice is recording at the time of xx.00 second).

Cleaning: When the reversal (i.e., negative spread) is found, those entries are erased, and then the bid and offer for those seconds are filled as those of just before.

(2) [Deals not on the bid or ask] Deals are recorded not exactly on the bid or ask.

Comments: This happens for two reasons. First, there are multiple deals during a one-second interval. Each may be on the bid and ask of the moment. But only the lowest given and the highest paid are recorded. The bid and ask may move during the one-second period. Therefore it is deviated at the one-second slice data. Second, deals may not occur at the ask or bid price, due to credit line constraints.

(3) [Reversal of Recorded Deals] Some recorded deals show reversal of bid-ask Comments: Could it be possible that deals are recorded some time (a second or two, or even a fraction of second) later than actual deal. Between the time of deal done and the recording of such a deal, a new bid or offer may show up. 
Table 1-1: Foreign Exchange Turnovers by Region

Geographical distribution of reported foreign exchange market turnover Daily averages in April, in billions ofUSD, 2001

\begin{tabular}{l|l|r|r}
\hline \multicolumn{2}{l|}{} & Amount & \% share \\
\hline Asia & Japan & 147 & 9.1 \\
& rest & 168 & 10.3 \\
\hline Europe & UK & 504 & 31.1 \\
& rest & 319 & 19.7 \\
\hline North America & US & 254 & 15.7 \\
& Canada & 42 & 2.6 \\
\hline Oceania & & 56 & 3.4 \\
\hline Total & & 1618 & 100 \\
\hline
\end{tabular}

Data source: Triennial Central Bank Survey 2001, BIS.

Notes: The reported foreign exchange market turnover, adjusted for local double-counting ("net-gross"). Since there are other regions that are not included in the four regions, the sum of the four regions do not add up to 100 percent. Aggregation of markets by author.

Original Source: Table B.7, BIS(2002): Triennial Central Bank Survey 2001.

Table 1-2: Dollar/Yen Turnovers by Region

Unit: daily average, in millions of USD

\begin{tabular}{l|l|r|r}
\hline & & Amount & \% share \\
\hline Asia & Japan & 101634 & 31.2 \\
& rest & 37020 & 11.4 \\
\hline \multirow{2}{*}{ Europe } & UK & 74382 & 22.9 \\
& rest & 32960 & 101 \\
\hline \multirow{2}{*}{ North AmericaUS } & 62145 & 19.1 \\
& Canada & 3287 & 1.0 \\
\hline Oceania & & 7434 & 2.3 \\
\hline Total & & 325464 & 100 \\
\hline
\end{tabular}

Data source: BIS, Triennial Central Bank Survey 2001

Notes: The US dollar against the yen turnover, net of local inter-dealer, double-counting by country and currency, in April 2001. Aggregation of markets by author.

Original Source: Table E-5, BIS(2002): Triennial Central Bank Survey 2001. 
Table 2: Data summary; Jan 1, 1999 - December 28, 2001, excluding Saturdays, Sundays, and national holidays (in at least one of the three major markets)

\begin{tabular}{|c|c|c|}
\hline \multicolumn{3}{|l|}{ Quote } \\
\hline \multicolumn{3}{|l|}{ Raw data } \\
\hline \multicolumn{2}{|c|}{ Number of price changes } & $8,501,732$ \\
\hline \multicolumn{3}{|l|}{ Filtered data } \\
\hline \multicolumn{2}{|c|}{ Number of price changes } & $8,429,303$ \\
\hline \multicolumn{2}{|c|}{ bid-side only } & $4,776,979$ \\
\hline \multicolumn{2}{|r|}{ ask-side only } & $4,908,881$ \\
\hline \multirow[t]{4}{*}{ spread } & mean & 0.020846 \\
\hline & variance & 0.000261 \\
\hline & skew & 1.727 \\
\hline & kurtosis & 7.492 \\
\hline \multicolumn{3}{|c|}{ Price change with negative bid-ask spread } \\
\hline \multicolumn{2}{|c|}{ number of price changes } & 72,429 \\
\hline \multicolumn{2}{|c|}{ average spread (absolute value) } & 0.010155 \\
\hline \multicolumn{3}{|l|}{ Deal } \\
\hline \multicolumn{3}{|c|}{ Number of deals } \\
\hline \multicolumn{2}{|c|}{ bid-side } & $3,113,109$ \\
\hline \multicolumn{2}{|c|}{ ask-side } & $3,287,321$ \\
\hline \multicolumn{3}{|c|}{ Deals with negative bid-ask spread } \\
\hline \multicolumn{2}{|c|}{ number of deals } & 24,119 \\
\hline \multicolumn{2}{|c|}{ spread (absolute value) } & 0.005375 \\
\hline
\end{tabular}


Table 3: T-test for difference between two GMT hours

\begin{tabular}{|c|c|c|c|c|c|c|}
\hline \multirow{2}{*}{$\frac{\text { hour }}{0,1}$} & \multicolumn{2}{|c|}{ quote revisions } & \multicolumn{2}{|l|}{ deals } & \multicolumn{2}{|c|}{ bid-ask spread } \\
\hline & 7.670 & $* * *$ & 3.526 & $* * *$ & 7.991 & $* * *$ \\
\hline 1,2 & 10.819 & $* * *$ & 9.814 & $* * *$ & -0.207 & \\
\hline 2,3 & 19.609 & $* * *$ & 17.899 & $* * *$ & -7.150 & $* * *$ \\
\hline 3,4 & -15.516 & $* * *$ & -12.891 & $* * *$ & 1.766 & \\
\hline 4,5 & -9.650 & $* * *$ & -9.219 & $* * *$ & 6.822 & $* * *$ \\
\hline 5,6 & -9.276 & $* * *$ & -9.450 & $* * *$ & 1.776 & \\
\hline 6,7 & -3.763 & $* * *$ & -5.102 & $* * *$ & 1.567 & \\
\hline 7,8 & -0.867 & & -0.672 & & -1.761 & \\
\hline 8,9 & 6.437 & $* * *$ & 7.826 & $* * *$ & -5.377 & $* * *$ \\
\hline 9,10 & 5.963 & $* * *$ & 8.377 & $* * *$ & -9.309 & $* * *$ \\
\hline 10,11 & 0.390 & & 1.758 & & -4.078 & $* * *$ \\
\hline 11,12 & -13.080 & $* * *$ & -12.662 & $* * *$ & 4.737 & $* * *$ \\
\hline 12,13 & -8.148 & $* * *$ & -7.535 & $* * *$ & 3.496 & $* * *$ \\
\hline 13,14 & -2.265 & & -1.782 & & 0.824 & \\
\hline 14,15 & 7.084 & $* * *$ & 7.132 & $* * *$ & -5.818 & $* * *$ \\
\hline 15,16 & 14.749 & $* * *$ & 12.834 & $* * *$ & -10.284 & $* * *$ \\
\hline 16,17 & 14.022 & $* * *$ & 12.331 & $* * *$ & -6.843 & $* * *$ \\
\hline 17,18 & 3.250 & $* * *$ & 4.532 & $* * *$ & -2.268 & \\
\hline 18,19 & 7.249 & $* * *$ & 6.429 & $* * *$ & -0.685 & \\
\hline 19,20 & 10.884 & $* * *$ & 8.599 & $* * *$ & -1.762 & \\
\hline 20,21 & 12.467 & $* * *$ & 10.720 & $* * *$ & 0.533 & \\
\hline 21,22 & 1.210 & & 0.341 & & 4.927 & $* * *$ \\
\hline 22,23 & -13.441 & $* * *$ & -15.357 & $* * *$ & 5.111 & $* * *$ \\
\hline 23,0 & 37.592 & $* * *$ & 35.332 & $* * *$ & -2.801 & $* * *$ \\
\hline
\end{tabular}

***: significant at $1 \%$

$* *$ : significant at $5 \%$ 
Table 4-1: Intraday timeline: GMT Clock and corresponding Local time of the three major markets

\begin{tabular}{c|rrrrrrrrrrrrrrrrrrrrrrrr} 
Normal (Winter) \\
\hline GMT & 0 & 1 & 2 & $\underline{\mathbf{3}}$ & 4 & 5 & 6 & 7 & 8 & 9 & 10 & $\underline{\mathbf{1 1}}$ & $\underline{\mathbf{1 2}}$ & 13 & 14 & 15 & 16 & 17 & 18 & 19 & 20 & 21 & $\underline{\mathbf{2 2}}$ & 23 \\
\hline \hline Tokyo & 9 & 10 & 11 & $\underline{\mathbf{1 2}}$ & 13 & 14 & 15 & 16 & 17 & 18 & 19 & 20 & 21 & 22 & 23 & +0 & +1 & +2 & +3 & +4 & +5 & +6 & +7 & +8 \\
\hline London & 0 & 1 & 2 & 3 & 4 & 5 & 6 & 7 & 8 & 9 & 10 & $\underline{\mathbf{1 1}}$ & $\underline{\mathbf{1 2}}$ & 13 & 14 & 15 & 16 & 17 & 18 & 19 & 20 & 21 & 22 & 23 \\
\hline NY & -19 & -20 & -21 & -22 & -23 & 0 & 1 & 2 & 3 & 4 & 5 & 6 & 7 & 8 & 9 & 10 & 11 & 12 & 13 & 14 & 15 & 16 & $\underline{\mathbf{1 7}}$ & 18 \\
\hline
\end{tabular}

Daylight saving time (Summer)

\begin{tabular}{|c|c|c|c|c|c|c|c|c|c|c|c|c|c|c|c|c|c|c|c|c|c|c|c|c|}
\hline GMT & 0 & 1 & 2 & $\underline{3}$ & 4 & 5 & 6 & 7 & 8 & 9 & $\underline{10}$ & 11 & 12 & 13 & 14 & 15 & 16 & 17 & 18 & 19 & 20 & 21 & 22 & 23 \\
\hline Tokyo & 9 & 10 & 11 & 12 & 13 & 14 & 15 & 16 & 17 & 18 & 79 & 20 & 21 & 22 & 23 & $\overline{c+0}$ & +1 & +2 & +3 & +4 & +5 & +6 & +7 & +8 \\
\hline London & 1 & 2 & 3 & 4 & 5 & 6 & 7 & 8 & 9 & 10 & $\underline{11}$ & 12 & 13 & 14 & 15 & 16 & 17 & 18 & 19 & 20 & 21 & 22 & 23 & +0 \\
\hline $\mathrm{NY}$ & -20 & -21 & -22 & -23 & 0 & 1 & 2 & 3 & 4 & 5 & 6 & 7 & 8 & 9 & 10 & 11 & 12 & 13 & 14 & 15 & 16 & $\underline{17}$ & 18 & 19 \\
\hline \multicolumn{25}{|c|}{ March-April (1week) } \\
\hline GMT & 0 & 1 & 2 & $\underline{\underline{3}}$ & 4 & 5 & 6 & 7 & 8 & 9 & $\underline{10}$ & $\underline{11}$ & 12 & 13 & 14 & 15 & 16 & 17 & 18 & 19 & 20 & 21 & $\underline{22}$ & 23 \\
\hline Tokyo & 9 & 10 & 11 & $\underline{12}$ & 13 & 14 & 15 & 16 & 17 & 18 & 19 & 20 & 21 & 22 & 23 & +0 & +1 & +2 & +3 & +4 & +5 & +6 & +7 & +8 \\
\hline London & 1 & 2 & 3 & 4 & 5 & 6 & 7 & 8 & 9 & 10 & $\underline{11}$ & $\underline{12}$ & 13 & 14 & 15 & 16 & 17 & 18 & 19 & 20 & 21 & 22 & 23 & +0 \\
\hline $\mathrm{NY}$ & -19 & -20 & -21 & -22 & -23 & 0 & 1 & 2 & 3 & 4 & 5 & 6 & 7 & 8 & 9 & 10 & 11 & 12 & 13 & 14 & 15 & 16 & $\underline{17}$ & 18 \\
\hline
\end{tabular}

Peaks of activities are Hours 0,8,13-15 in the winter; Hours0,7,12-14 in the summer i

Troughs of activities are Hours 3,10-11, and 22 in the winter; Hours 3,10-11, 21 in the summes $\underline{\boldsymbol{i}}$

Table 4-2: Adjusted GMT Clock and corresponding Local time of the three major markets

Adjusted GMT clock
\begin{tabular}{c|rrrrrrrrrrrrrrrrrrrrrrrrr} 
GMT & 0 & 1 & 2 & $\mathbf{3}$ & 4 & 5 & 6 & 7 & 8 & 9 & $\mathbf{1 0}$ & $\mathbf{1 1}$ & 12 & 13 & 14 & 15 & 16 & 17 & 18 & 19 & 20 & $\mathbf{2 1}$ & 22 & 23 & 24 \\
\hline \hline Tokyo(w) & 9 & 10 & 11 & $\mathbf{1 2}$ & 13 & 14 & 15 & 16 & 17 & 18 & 19 & 20 & 21 & 22 & 23 & +0 & +1 & +2 & +3 & +4 & +5 & +6 & +7 & +8 & $(\mathrm{x})$ \\
Tokyo(s) & 9 & 10 & 11 & 12 & 13 & 14 & $(\mathrm{x})$ & 15 & 16 & 17 & 18 & 19 & 20 & 21 & 22 & 23 & +0 & +1 & +2 & +3 & +4 & +5 & +6 & +7 & +8 \\
\hline London(w) & 0 & 1 & 2 & 3 & 4 & 5 & 6 & 7 & 8 & 9 & 10 & $\mathbf{1 1}$ & $\mathbf{1 2}$ & 13 & 14 & 15 & 16 & 17 & 18 & 19 & 20 & 21 & 22 & 23 & $(\mathrm{x})$ \\
London(s) & 1 & 2 & 3 & 4 & 5 & 6 & $(\mathrm{x})$ & 7 & 8 & 9 & 10 & $\mathbf{1 1}$ & $\mathbf{1 2}$ & 13 & 14 & 15 & 16 & 17 & 18 & 19 & 20 & 21 & 22 & 23 & +1 \\
\hline NY(w) & -19 & -20 & -21 & -22 & -23 & 0 & 1 & 2 & 3 & 4 & 5 & 6 & 7 & 8 & 9 & 10 & 11 & 12 & 13 & 14 & 15 & 16 & $\mathbf{1 7}$ & 18 & $(\mathrm{x})$ \\
$\mathrm{NY}(\mathrm{s})$ & -20 & -21 & -22 & -23 & 0 & 1 & $(\mathrm{x})$ & 2 & 3 & 4 & 5 & 6 & 7 & 8 & 9 & 10 & 11 & 12 & 13 & 14 & 15 & 16 & $\mathbf{1 7}$ & 18 & 19 \\
\hline
\end{tabular}


Table 5-1: Deals and Quote revisions

\begin{tabular}{cccrc}
\multicolumn{7}{l}{ dependent variable: number of deals } \\
\hline \multicolumn{7}{c}{ Constant } & s.e. & quote revision & \multicolumn{1}{c}{ s.e. } \\
\hline whole sample & $-154.381 * * *$ & 1.89066 & $1.06831 * * *$ & $3.32 \mathrm{E}-03$ \\
1999 & $-212.836 * * *$ & 4.27835 & $1.2116 * * *$ & $6.89 \mathrm{E}-03$ \\
2000 & $-120.585 * * *$ & 2.32828 & $1.00376 * * *$ & $4.60 \mathrm{E}-03$ \\
2001 & $-118.118 * * *$ & 2.53696 & $0.949443 * * *$ & $4.39 \mathrm{E}-03$ \\
\hline
\end{tabular}

number of deals $=$ constant $+\alpha^{*}$ number of quote revision

$(-154.4) \quad(1.07)$

Table 5-2:

Panel A: Hour 0 effect and correlation between number of quote revisions and spread

Dependent variable: mean of spread

Hour 0 effect

\begin{tabular}{|c|c|c|c|c|c|c|c|}
\hline & Constant & & s.e. & quote revision & s.e. & Hour0 dummy & s.e. \\
\hline$\overline{\text { whole sample }}$ & 0.02285 & $* * *$ & $1.42 \mathrm{E}-04$ & $-3.99 \mathrm{E}-06 * * *$ & $2.54 \mathrm{E}-07$ & $-3.89 \mathrm{E}-07$ & $4.78 \mathrm{E}-07$ \\
\hline 1999 & 0.02595 & $* * *$ & $3.38 \mathrm{E}-04$ & $-6.74 \mathrm{E}-06 * * *$ & $5.56 \mathrm{E}-07$ & $1.08 \mathrm{E}-06$ & $9.67 \mathrm{E}-07$ \\
\hline 2000 & 0.02100 & $* * *$ & $1.75 \mathrm{E}-04$ & $-3.34 \mathrm{E}-06 * * *$ & $3.52 \mathrm{E}-07$ & $-1.14 \mathrm{E}-06 * *$ & $6.57 \mathrm{E}-07$ \\
\hline 2001 & 0.02266 & $* * *$ & $2.01 \mathrm{E}-04$ & $-3.58 \mathrm{E}-06 * * *$ & $3.52 \mathrm{E}-07$ & $-1.37 \mathrm{E}-06 * *$ & 7.13E-07 \\
\hline
\end{tabular}

mean of spread $=$ constant $+\alpha^{*}$ number of quote revision $+\beta^{*}$ HOdummy*number of quote revision

$$
\text { (0.023) (-3.99E-06) (3.89E-07) }
$$

Panel B: Hour 0 effect and Correlation between number of deals and spread

Dependent variable: mean of spread

Hour 0 effect

\begin{tabular}{|c|c|c|c|c|c|c|c|}
\hline & Constant & & s.e. & number of deals & s.e. & Hour0 dummy & s.e. \\
\hline whole sample & 0.0229 & $* * *$ & I $06 \mathrm{~b}-04$ & $-5.40 \mathrm{E}-06 * * *$ & 2.JBE-ם? & $5.58 \mathrm{E}-07$ & $5.51 \mathrm{~L}-\mathrm{C} ?$ \\
\hline 1999 & 0.0248 & $* * *$ & 244E-04 & $-5.75 \mathrm{E}-06 * * *$ & 4.]. $\mathrm{EE}-\mathrm{C} ?$ & $1.32 \mathrm{E}-06$ & 1.03E-व \\
\hline 2000 & 0.0215 & $* * *$ & I. $31 \mathrm{IE}-04$ & $-6.23 \mathrm{E}-06 * * *$ & Э ट己टE-0? & $-3.90 \mathrm{E}-07$ & 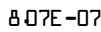 \\
\hline 2001 & 0.0233 & $* * *$ & $1.54 \mathrm{E}-04$ & $-6.80 \mathrm{E}-06 * * *$ & उमटE - $7 ?$ & $-4.88 \mathrm{E}-07$ & В.गटE - ? \\
\hline
\end{tabular}

mean of spread $=$ constant $+\alpha *$ number of deals $+\beta *$ H0dummy*number of deals

$$
\text { (0.023) (-5.40E-06) (5.58E-07) }
$$


Table 5-3

Panel A: Monday opening (Hour 0) effect and correlation between the number of quote revisions and spread.

Dependent variable: mean of spread

Monday Hour 0 effect

\begin{tabular}{|c|c|c|c|c|c|c|c|}
\hline & Constant & & s.e. & quote revision & s.e. & Monday HO dumm & s.e. \\
\hline full sample & 0.02287 & $* * *$ & $1.42 \mathrm{E}-04$ & $-4.05 \mathrm{E}-06 * * *$ & $2.50 \mathrm{E}-07$ & $9.36 \mathrm{E}-07$ & $1.09 \mathrm{E}-06$ \\
\hline 1999 & 0.02592 & $* * *$ & 3.37E-04 & $-6.65 \mathrm{E}-06 * * *$ & $5.44 \mathrm{E}-07$ & $1.79 \mathrm{E}-06$ & $2.10 \mathrm{E}-06$ \\
\hline 2000 & 0.02103 & $* * *$ & $1.75 \mathrm{E}-04$ & $-3.47 \mathrm{E}-06 * * *$ & $3.47 \mathrm{E}-07$ & $1.17 \mathrm{E}-06$ & $1.52 \mathrm{E}-06$ \\
\hline 2001 & 0.02267 & $* * *$ & $2.01 \mathrm{E}-04$ & $-3.67 \mathrm{E}-06 * * *$ & $3.49 \mathrm{E}-07$ & $-3.70 \mathrm{E}-07$ & $1.74 \mathrm{E}-06$ \\
\hline
\end{tabular}

mean of spread $=$ constant $+\alpha^{*}$ number of quote revision $+\beta^{*}$ MondayH0dummy*number of quote revision

$$
\text { (0.023) (-4.05E-06) (9.36E-07) }
$$

Panel B: Monday opening (Hour 0) effect and correlation between number of deals and spread

Dependent variable: mean of spread

Monday Hour 0 effect

\begin{tabular}{|c|c|c|c|c|c|c|c|}
\hline & Constant & & s.e. & number of deals & s.e. & Monday H0 dumm & s.e. \\
\hline full sample & 0.0229 & $* * *$ & I. $0 \mathrm{bE}-04$ & $-5.39 \mathrm{E}-06 * * *$ & 2.15E-0? & $2.19 \mathrm{E}-06 * *$ & $\mathrm{I}, 24 \mathrm{E}-\mathrm{Db}$ \\
\hline 1999 & 0.0248 & $* * *$ & 244E-04 & $-5.68 \mathrm{E}-06 * * *$ & 4.] 2 E-0 ?$ & $2.23 \mathrm{E}-06$ & 己ᄅ๖E-마 \\
\hline 2000 & 0.0215 & $* * *$ & $\mathrm{I}, 3 \mathrm{l} \mathrm{E}-\mathrm{-04}$ & $-6.31 \mathrm{E}-06 * * *$ & 3.19E-व? & $2.91 \mathrm{E}-06 *$ & I.78E- \\
\hline 2001 & 0.0233 & $* * *$ & $1.54 E-04$ & $-6.83 \mathrm{E}-06 * * *$ & 3.3. $\mathrm{E}-0 ?$ & 4.68E-07 & 己. \\
\hline
\end{tabular}

mean of spread $=$ constant $+\alpha^{*}$ number of deals $+\beta^{*}$ MondayHOdummy*number of deals

(0.023) (-5.39E-06) (2.19E-06) 
Table 5-4

Panel A: regression of Number of Price Change on Dummy

\begin{tabular}{|c|c|c|c|c|c|c|c|c|c|c|c|c|}
\hline & $\begin{array}{l}\text { all } \\
\text { Coefficient }\end{array}$ & & s.e. & $\begin{array}{l}1999 \\
\text { Coefficient }\end{array}$ & & s.e. & $\begin{array}{l}2000 \\
\text { Coefficient }\end{array}$ & & s.e. & $\begin{array}{l}2001 \\
\text { Coefficient }\end{array}$ & & s.e. \\
\hline$\overline{\mathrm{C}}$ & 272.31 & $* * *$ & 7.23 & 314.60 & *** & 13.94 & 249.51 & $* * *$ & 10.39 & 254.27 & **** & 11.90 \\
\hline HODUM & 414.92 & $* * *$ & 10.22 & 500.85 & $* * *$ & 19.72 & 358.77 & $* * *$ & 14.69 & 388.17 & $* * *$ & 16.83 \\
\hline H1DUM & 319.66 & $* * *$ & 10.22 & 358.63 & $* * *$ & 19.72 & 269.31 & $* * *$ & 14.69 & 332.62 & $* * *$ & 16.83 \\
\hline H2DUM & 189.72 & $* * *$ & 10.22 & 227.35 & $* * *$ & 19.72 & 141.57 & $* * *$ & 14.69 & 201.77 & $* * *$ & 16.83 \\
\hline H3DUM & -4.93 & & 10.22 & -15.49 & & 19.72 & -28.00 & $* *$ & 14.69 & 28.59 & $* *$ & 16.83 \\
\hline H4DUM & 136.24 & $* * *$ & 10.22 & 146.81 & $* * *$ & 19.72 & 90.38 & $* * *$ & 14.69 & 172.23 & $* * *$ & 16.83 \\
\hline H5DUM & 240.82 & $* * *$ & 10.22 & 298.05 & $* * *$ & 19.72 & 184.19 & $* * *$ & 14.69 & 242.41 & $* * *$ & 16.83 \\
\hline H6DUM & 249.95 & $* * *$ & 12.32 & 273.53 & $* * *$ & 23.84 & 232.56 & $* * *$ & 17.57 & 243.20 & $* * *$ & 20.37 \\
\hline H7DUM & 253.90 & $* * *$ & 13.17 & 231.45 & $* * *$ & 25.38 & 247.17 & $* * *$ & 18.81 & 281.22 & $* * *$ & 21.84 \\
\hline H8DUM & 366.59 & $* * *$ & 10.62 & 386.38 & $* * *$ & 20.43 & 314.41 & $* * *$ & 15.28 & 400.45 & $* * *$ & 17.51 \\
\hline H9DUM & 331.80 & $* * *$ & 10.22 & 326.03 & $* * *$ & 19.72 & 287.91 & $* * *$ & 14.69 & 381.65 & $* * *$ & 16.83 \\
\hline H10DUM & 268.24 & $* * *$ & 10.22 & 242.06 & $* * *$ & 19.72 & 249.27 & $* * *$ & 14.69 & 312.77 & $* * *$ & 16.83 \\
\hline H11DUM & 283.13 & $* * *$ & 10.58 & 243.78 & $* * *$ & 20.36 & 266.05 & $* * *$ & 15.22 & 338.93 & $* * *$ & 17.43 \\
\hline H12DUM & 281.68 & $* * *$ & 12.35 & 234.21 & $* * *$ & 23.90 & 268.68 & $* * *$ & 17.62 & 342.13 & $* * *$ & 20.43 \\
\hline H13DUM & 338.44 & $* * *$ & 13.51 & 276.31 & $* * *$ & 26.00 & 301.86 & $* * *$ & 19.28 & 439.18 & $* * *$ & 22.46 \\
\hline H14DUM & 381.17 & $* * *$ & 13.32 & 304.74 & $* * *$ & 25.64 & 354.74 & $* * *$ & 19.03 & 485.64 & $* * *$ & 22.12 \\
\hline H15DUM & 400.12 & $* * *$ & 10.63 & 365.62 & $* * *$ & 20.44 & 368.89 & $* * *$ & 15.29 & 466.94 & $* * *$ & 17.52 \\
\hline H16DUM & 301.66 & $* * *$ & 12.10 & 298.75 & $* * *$ & 23.43 & 277.09 & $* * *$ & 17.27 & 329.93 & $* * *$ & 19.98 \\
\hline H17DUM & 115.35 & $* * *$ & 10.22 & 116.87 & $* * *$ & 19.72 & 102.79 & $* * *$ & 14.69 & 126.52 & $* * *$ & 16.83 \\
\hline H18DUM & 86.15 & $* * *$ & 10.22 & 93.10 & $* * *$ & 19.72 & 62.30 & $* * *$ & 14.69 & 103.45 & $* * *$ & 16.83 \\
\hline H19DUM & 29.75 & $* * *$ & 10.22 & 11.29 & & 19.72 & 32.87 & $* *$ & 14.69 & 44.53 & $* * *$ & 16.83 \\
\hline H20DUM & -36.45 & $* * *$ & 10.22 & -67.55 & $* * *$ & 19.72 & -28.51 & $* *$ & 14.69 & -14.28 & & 16.83 \\
\hline H21DUM & -101.77 & $* * *$ & 10.22 & -129.06 & $* * *$ & 19.72 & -88.84 & $* * *$ & 14.69 & -88.33 & $* * *$ & 16.83 \\
\hline H22DUM & -108.76 & $* * *$ & 10.22 & -119.68 & $* * *$ & 19.72 & -106.43 & $* * *$ & 14.69 & -100.52 & $* * *$ & 16.83 \\
\hline LNOPEN & 173.48 & $* * *$ & 11.73 & 228.13 & $* * *$ & 22.73 & 125.30 & $* * *$ & 16.76 & 170.66 & $* * *$ & 19.36 \\
\hline LNOPEN2 & 174.03 & $* * *$ & 11.73 & 211.50 & $* * *$ & 22.73 & 120.26 & $* * *$ & 16.76 & 192.85 & $* * *$ & 19.36 \\
\hline NYOPEN & 173.44 & $* * *$ & 11.83 & 248.51 & $* * *$ & 22.90 & 142.62 & $* * *$ & 16.89 & 128.58 & $* * *$ & 19.55 \\
\hline NYOPEN2 & 189.38 & $* * *$ & 12.56 & 264.99 & $* * *$ & 24.25 & 170.72 & $* * *$ & 17.93 & 130.67 & $* * *$ & 20.83 \\
\hline NYOPEN3 & 214.22 & $* * * *$ & 11.83 & 255.97 & $* * *$ & 22.90 & 202.18 & $* * *$ & 16.89 & 183.56 & $* * *$ & 19.55 \\
\hline LNLUNCH & -62.08 & $* * *$ & 11.05 & -65.42 & $* * *$ & 21.46 & -78.03 & $* * *$ & 15.79 & -44.41 & $* * *$ & 18.17 \\
\hline
\end{tabular}

Note: ***, ** and $*$ indicate the significance at the 1,5 , and $10 \%$, respectively. 
Table 5-4

Panel B: regression of Spread on Dummy

\begin{tabular}{|c|c|c|c|c|c|c|c|c|}
\hline & all & & 1999 & & 2000 & & 2001 & \\
\hline & Coefficient & s.e. & Coefficient & s.e. & Coefficient & s.e. & Coefficient & s.e. \\
\hline $\mathrm{C}$ & $0.02066 * * *$ & 3.03E-04 & $0.0229 * * *$ & 7.42E-04 & $0.019135 * * *$ & $3.38 \mathrm{E}-04$ & $0.020023 * * *$ & 4.00E-04 \\
\hline HODUM & $-1.43 \mathrm{E}-03 * * *$ & $4.28 \mathrm{E}-04$ & $-1.88 \mathrm{E}-03 * *$ & $1.05 \mathrm{E}-03$ & $-1.28 \mathrm{E}-03 * * *$ & 4.79E-04 & $-1.15 \mathrm{E}-03 * *$ & $5.65 \mathrm{E}-04$ \\
\hline H1DUM & $-3.64 \mathrm{E}-03 * * *$ & 4.28E-04 & $-4.65 \mathrm{E}-03 * * *$ & $1.05 \mathrm{E}-03$ & $-3.22 \mathrm{E}-03 * * *$ & 4.79E-04 & $-3.07 \mathrm{E}-03 * * *$ & $5.65 \mathrm{E}-04$ \\
\hline H2DUM & $-3.58 \mathrm{E}-03 * * *$ & $4.28 \mathrm{E}-04$ & $-4.83 \mathrm{E}-03 * * *$ & $1.05 \mathrm{E}-03$ & $-3.07 \mathrm{E}-03 * * *$ & 4.79E-04 & $-2.90 \mathrm{E}-03 * * *$ & $5.65 \mathrm{E}-04$ \\
\hline H3DUM & $-2.01 \mathrm{E}-03 * * *$ & $4.28 \mathrm{E}-04$ & $-2.57 \mathrm{E}-03 * * *$ & $1.05 \mathrm{E}-03$ & $-1.94 \mathrm{E}-03 * * *$ & 4.79E-04 & $-1.53 \mathrm{E}-03 * * *$ & 5.65E-04 \\
\hline H4DUM & $-2.37 \mathrm{E}-03 * * *$ & $4.28 \mathrm{E}-04$ & $-3.39 \mathrm{E}-03 * * *$ & $1.05 \mathrm{E}-03$ & $-1.94 \mathrm{E}-03 * * *$ & 4.79E-04 & $-1.83 \mathrm{E}-03 * * *$ & $5.65 \mathrm{E}-04$ \\
\hline H5DUM & $-3.60 \mathrm{E}-03 * * *$ & $4.28 \mathrm{E}-04$ & $-4.96 \mathrm{E}-03 * * *$ & $1.05 \mathrm{E}-03$ & $-2.92 \mathrm{E}-03 * * *$ & 4.79E-04 & $-2.95 \mathrm{E}-03 * * *$ & $5.65 \mathrm{E}-04$ \\
\hline H6DUM & $-3.46 \mathrm{E}-03 * * *$ & $5.16 \mathrm{E}-04$ & $-3.84 \mathrm{E}-03 * * *$ & $1.27 \mathrm{E}-03$ & $-3.15 \mathrm{E}-03 * * *$ & $5.73 \mathrm{E}-04$ & $-3.42 \mathrm{E}-03 * * *$ & $6.85 \mathrm{E}-04$ \\
\hline H7DUM & $-3.57 \mathrm{E}-03 * * *$ & $5.51 \mathrm{E}-04$ & $-3.60 \mathrm{E}-03 * * *$ & $1.35 \mathrm{E}-03$ & $-3.42 \mathrm{E}-03 * * *$ & $6.13 \mathrm{E}-04$ & $-3.72 \mathrm{E}-03 * * *$ & 7.34E-04 \\
\hline H8DUM & $-3.64 \mathrm{E}-03 * * *$ & $4.45 \mathrm{E}-04$ & $-4.57 \mathrm{E}-03 * * *$ & $1.09 \mathrm{E}-03$ & $-3.23 \mathrm{E}-03 * * *$ & $4.98 \mathrm{E}-04$ & $-3.19 \mathrm{E}-03 * * *$ & $5.88 \mathrm{E}-04$ \\
\hline H9DUM & $-2.51 \mathrm{E}-03 * * *$ & $4.28 \mathrm{E}-04$ & $-3.73 \mathrm{E}-03 * * *$ & $1.05 \mathrm{E}-03$ & $-1.99 \mathrm{E}-03 * * *$ & $4.79 \mathrm{E}-04$ & $-1.86 \mathrm{E}-03 * * *$ & $5.65 \mathrm{E}-04$ \\
\hline H10DUM & $-2.97 \mathrm{E}-04$ & $4.28 \mathrm{E}-04$ & $-1.40 \mathrm{E}-03 *$ & $1.05 \mathrm{E}-03$ & $3.75 \mathrm{E}-04$ & 4.79E-04 & $9.45 \mathrm{E}-05$ & $5.65 \mathrm{E}-04$ \\
\hline H11DUM & $3.92 \mathrm{E}-04$ & 4.43E-04 & $-4.14 \mathrm{E}-04$ & $1.08 \mathrm{E}-03$ & 7.78E-04* & $4.96 \mathrm{E}-04$ & $7.82 \mathrm{E}-04 *$ & $5.86 \mathrm{E}-04$ \\
\hline H12DUM & $6.01 \mathrm{E}-04$ & 5.17E-04 & $1.23 \mathrm{E}-03$ & $1.27 \mathrm{E}-03$ & $3.49 \mathrm{E}-04$ & $5.74 \mathrm{E}-04$ & $2.46 \mathrm{E}-04$ & $6.87 \mathrm{E}-04$ \\
\hline H13DUM & $1.58 \mathrm{E}-04$ & $5.66 \mathrm{E}-04$ & $1.36 \mathrm{E}-03$ & $1.38 \mathrm{E}-03$ & $-6.44 \mathrm{E}-04$ & $6.28 \mathrm{E}-04$ & $-2.39 \mathrm{E}-04$ & $7.55 \mathrm{E}-04$ \\
\hline H14DUM & $-5.87 \mathrm{E}-04$ & $5.58 \mathrm{E}-04$ & $-3.69 \mathrm{E}-04$ & $1.36 \mathrm{E}-03$ & $-8.68 \mathrm{E}-04 *$ & $6.20 \mathrm{E}-04$ & $-5.70 \mathrm{E}-04$ & 7.43E-04 \\
\hline H15DUM & $-7.20 \mathrm{E}-05$ & $4.45 \mathrm{E}-04$ & $-9.94 \mathrm{E}-04$ & $1.09 \mathrm{E}-03$ & $1.32 \mathrm{E}-04$ & $4.98 \mathrm{E}-04$ & $5.87 \mathrm{E}-04$ & $5.89 \mathrm{E}-04$ \\
\hline H16DUM & $1.29 \mathrm{E}-03$ *** & $5.07 \mathrm{E}-04$ & $8.47 \mathrm{E}-04$ & $1.25 \mathrm{E}-03$ & $1.07 \mathrm{E}-03 * *$ & $5.63 \mathrm{E}-04$ & $1.93 \mathrm{E}-03$ *** & $6.72 \mathrm{E}-04$ \\
\hline H17DUM & $4.91 \mathrm{E}-03 * * *$ & $4.28 \mathrm{E}-04$ & $4.51 \mathrm{E}-03 * * *$ & $1.05 \mathrm{E}-03$ & $4.36 \mathrm{E}-03 * * *$ & 4.79E-04 & $5.86 \mathrm{E}-03 * * *$ & $5.65 \mathrm{E}-04$ \\
\hline H18DUM & $6.05 \mathrm{E}-03 * * *$ & $4.28 \mathrm{E}-04$ & $6.74 \mathrm{E}-03 * * *$ & $1.05 \mathrm{E}-03$ & $5.00 \mathrm{E}-03$ **** & 4.79E-04 & $6.43 \mathrm{E}-03 * * *$ & $5.65 \mathrm{E}-04$ \\
\hline H19DUM & $6.60 \mathrm{E}-03 * * *$ & $4.28 \mathrm{E}-04$ & $6.73 \mathrm{E}-03 * * *$ & $1.05 \mathrm{E}-03$ & $6.05 \mathrm{E}-03 * * *$ & 4.79E-04 & 7.01E-03 *** & $5.65 \mathrm{E}-04$ \\
\hline H20DUM & 7.94E-03 *** & $4.28 \mathrm{E}-04$ & 7.43E-03 *** & $1.05 \mathrm{E}-03$ & $7.85 \mathrm{E}-03$ *** & 4.79E-04 & 8.53E-03 *** & $5.65 \mathrm{E}-04$ \\
\hline H21DUM & 7.61E-03 *** & $4.28 \mathrm{E}-04$ & $7.56 \mathrm{E}-03 * * *$ & $1.05 \mathrm{E}-03$ & $7.13 \mathrm{E}-03 * * *$ & 4.79E-04 & 8.13E-03 *** & $5.65 \mathrm{E}-04$ \\
\hline H22DUM & $3.78 \mathrm{E}-03 * * *$ & $4.28 \mathrm{E}-04$ & $3.59 \mathrm{E}-03 * * *$ & $1.05 \mathrm{E}-03$ & $3.58 \mathrm{E}-03 * * *$ & 4.79E-04 & 4.18E-03 *** & $5.65 \mathrm{E}-04$ \\
\hline LNOPEN & $-7.88 \mathrm{E}-04 *$ & 4.91E-04 & $-2.49 \mathrm{E}-03 * *$ & $1.21 \mathrm{E}-03$ & $-1.28 \mathrm{E}-04$ & $5.46 \mathrm{E}-04$ & $1.99 \mathrm{E}-04$ & $6.51 \mathrm{E}-04$ \\
\hline LNOPEN2 & $-7.91 \mathrm{E}-04 *$ & 4.91E-04 & $-2.30 \mathrm{E}-03 * *$ & $1.21 \mathrm{E}-03$ & $-2.65 \mathrm{E}-04$ & $5.46 \mathrm{E}-04$ & 1.49E-04 & $6.51 \mathrm{E}-04$ \\
\hline NYOPEN & $-1.23 \mathrm{E}-03 * * *$ & $4.95 \mathrm{E}-04$ & $-2.91 \mathrm{E}-03 * * *$ & $1.22 \mathrm{E}-03$ & $-6.06 \mathrm{E}-04$ & $5.50 \mathrm{E}-04$ & $-1.98 \mathrm{E}-04$ & $6.57 \mathrm{E}-04$ \\
\hline NYOPEN2 & $-2.18 \mathrm{E}-03 * * *$ & $5.26 \mathrm{E}-04$ & $-5.06 \mathrm{E}-03 * * *$ & $1.29 \mathrm{E}-03$ & $-8.96 \mathrm{E}-04 *$ & $5.84 \mathrm{E}-04$ & $-6.45 \mathrm{E}-04$ & $7.00 \mathrm{E}-04$ \\
\hline NYOPEN3 & $-1.96 \mathrm{E}-03 * * *$ & 4.95E-04 & $-4.57 \mathrm{E}-03 * * *$ & $1.22 \mathrm{E}-03$ & $-9.51 \mathrm{E}-04 * *$ & 5.50E-04 & $-4.29 \mathrm{E}-04$ & $6.57 \mathrm{E}-04$ \\
\hline LNLUNCH & $2.04 \mathrm{E}-03 * * *$ & 4.63E-04 & $1.46 \mathrm{E}-03$ & $1.14 \mathrm{E}-03$ & $2.02 \mathrm{E}-03 * * *$ & $5.14 \mathrm{E}-04$ & $2.61 \mathrm{E}-03 * * *$ & $6.11 \mathrm{E}-04$ \\
\hline
\end{tabular}

Note: $* * *, * *$ and $*$ indicate the significance at the 1,5 , and $10 \%$, respectively. 
Figure 1: An illustration of price changes and transactions with negative spread

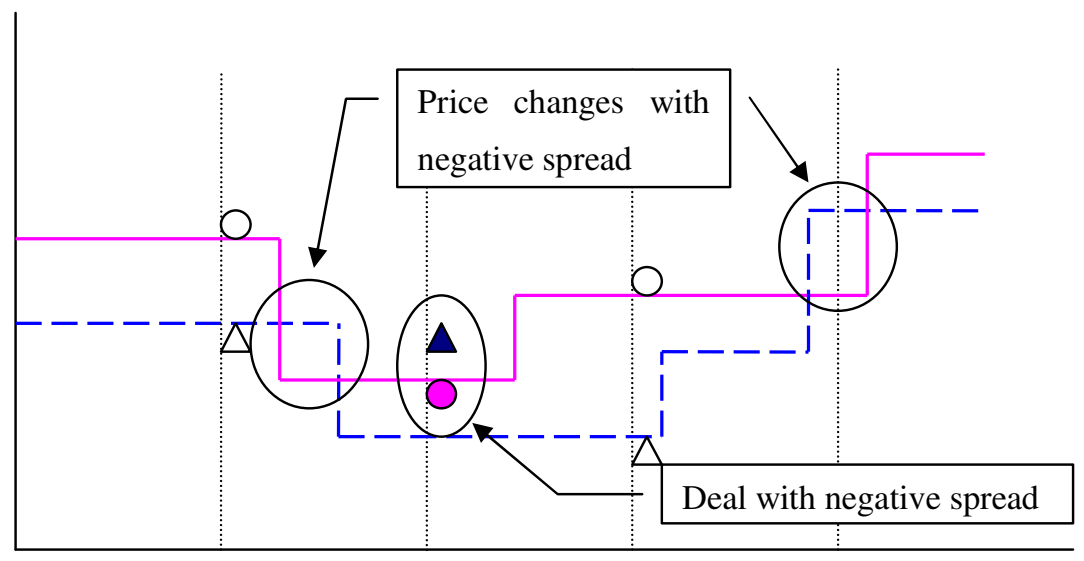


Figure 2-1: Summer 1999

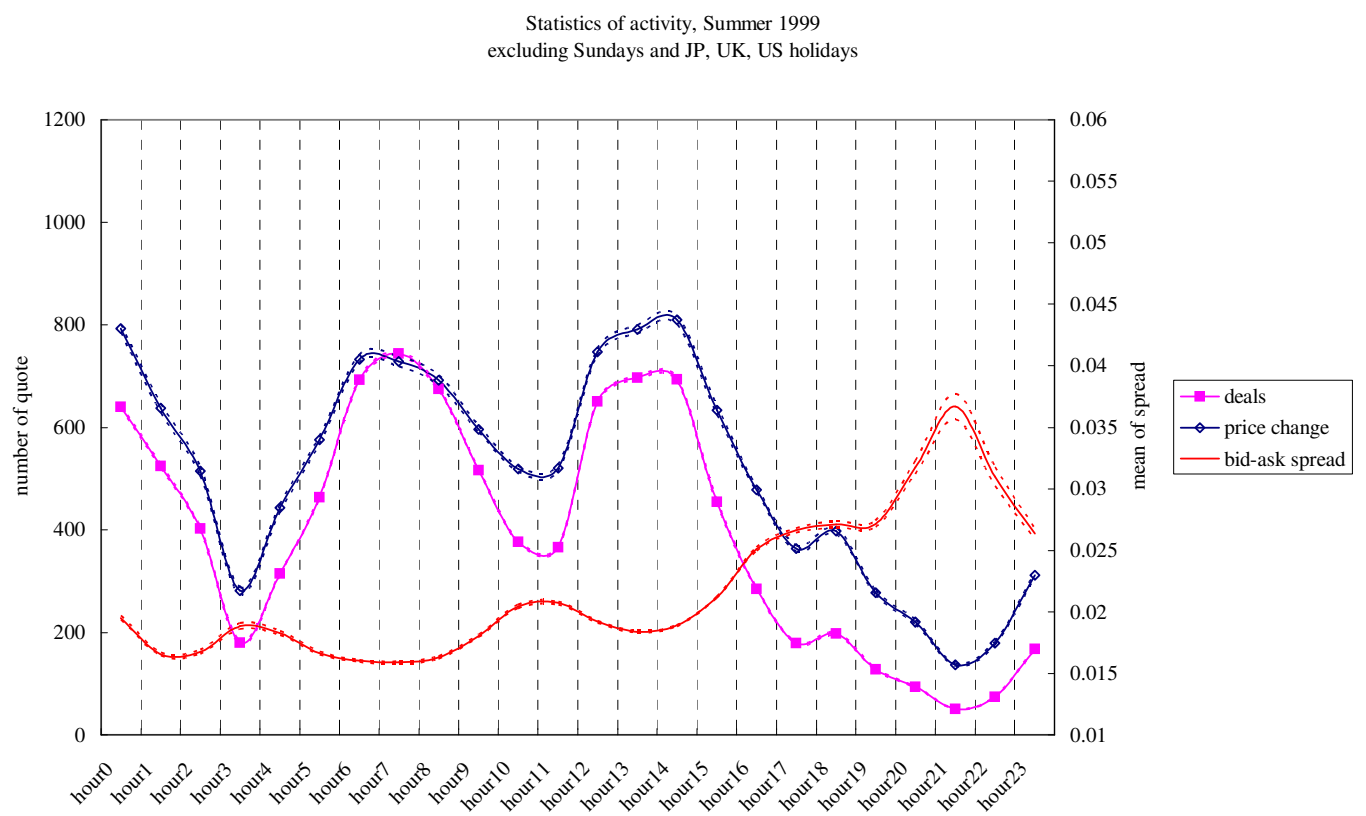

Figure 2-2: Summer 2000

Statistics of activity, Summer 2000 excluding Sundays and JP, UK, US holidays

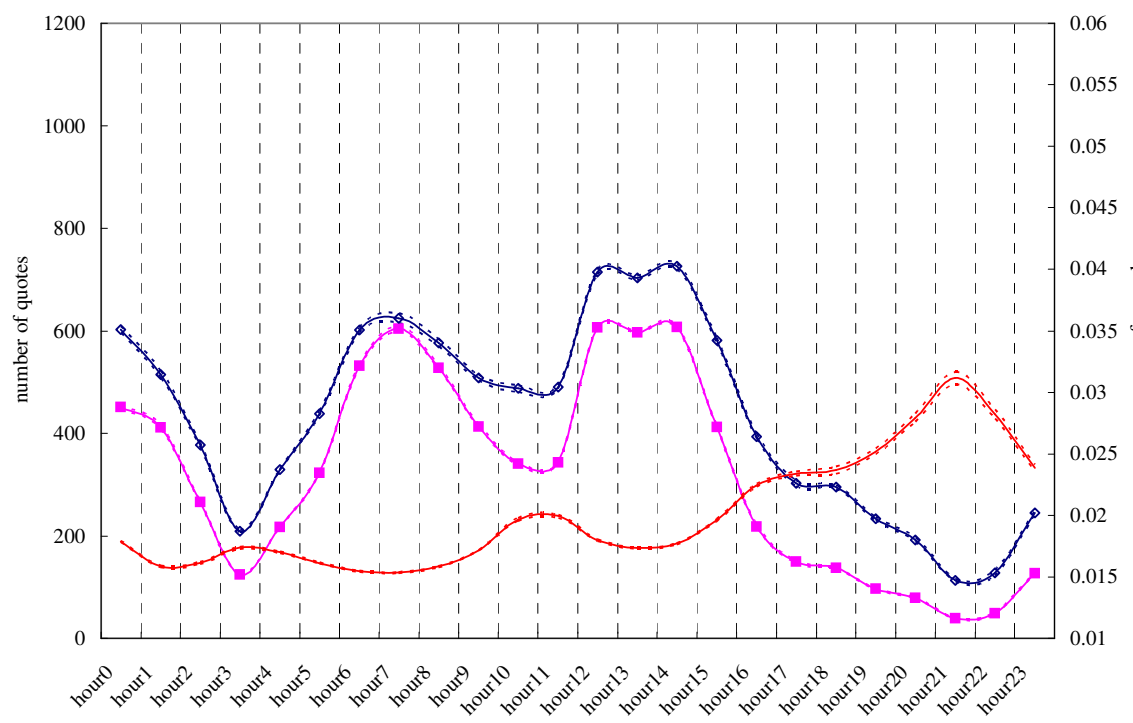


Figure 2-3: Summer 2001

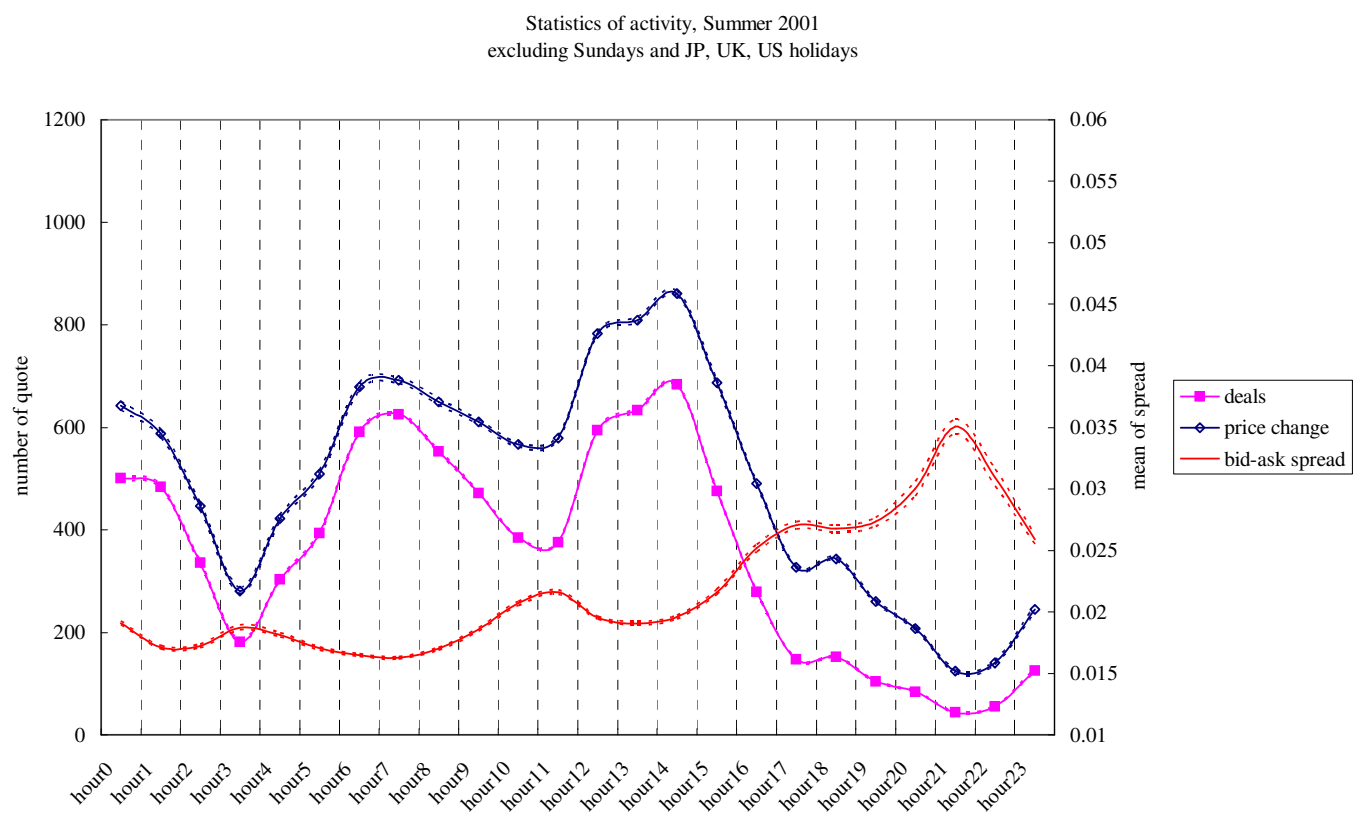

Figure 2-4: Winter 1999

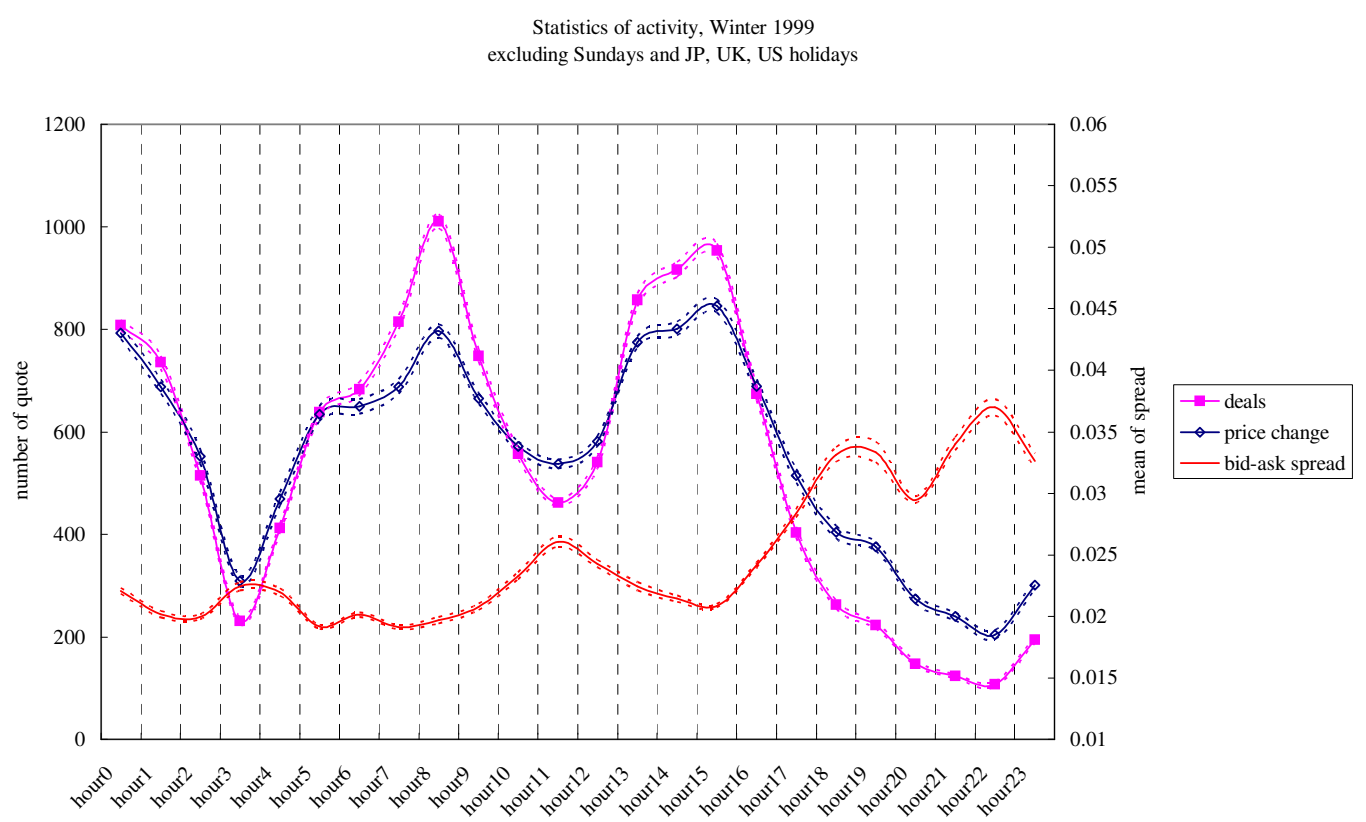


Figure 2-5: Winter 2000

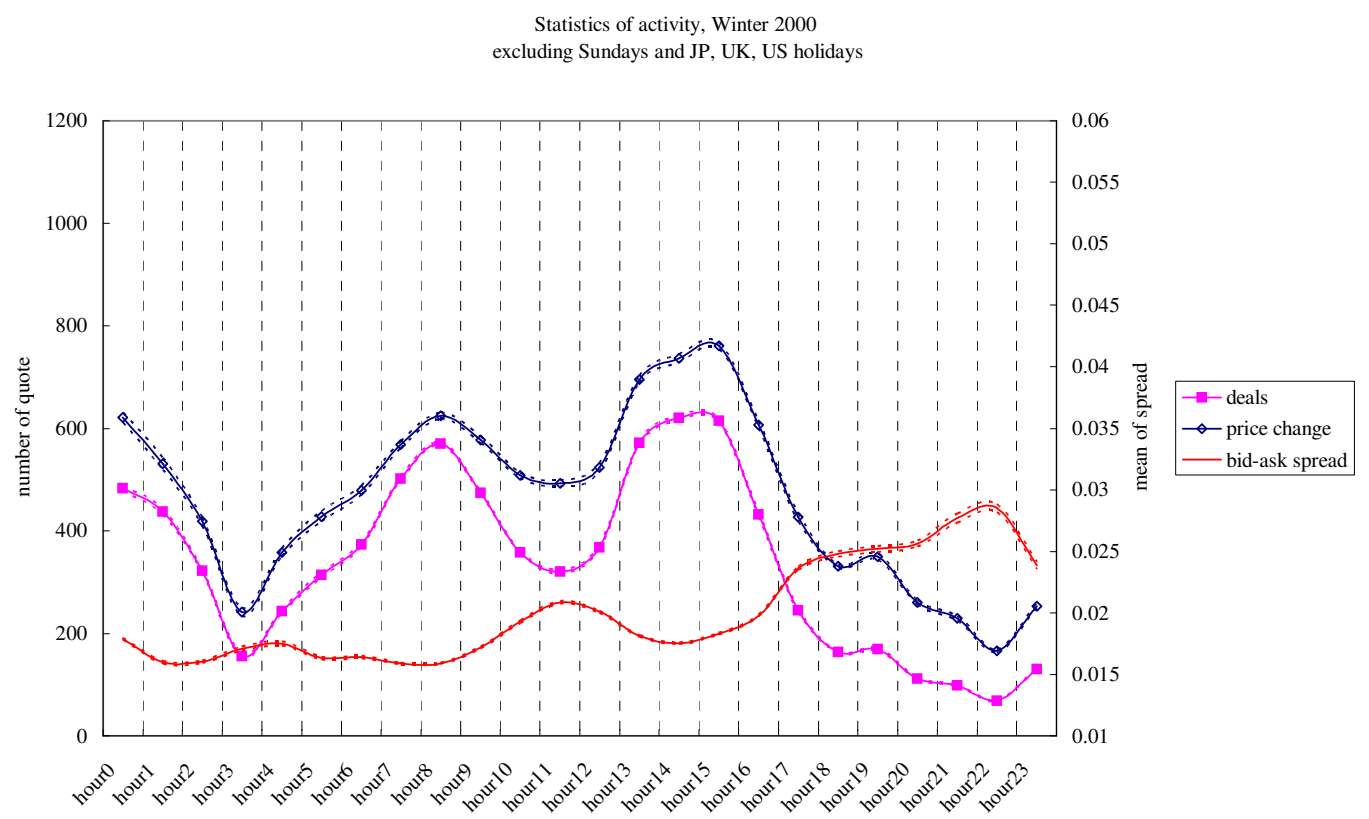

Figure 2-6: Winter 2001

Statistics of activity, Winter 2001

excluding Sundays and JP, UK, US holidays

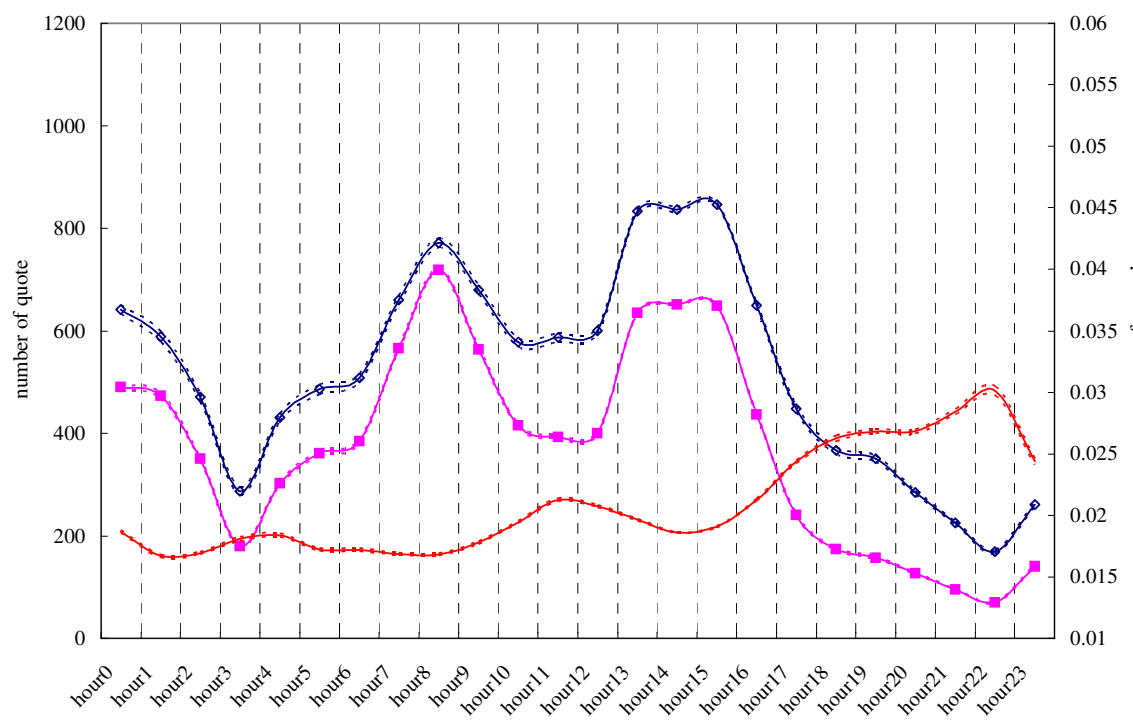

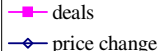

bid-ask spread 
Figure 3-1: The year of 1999

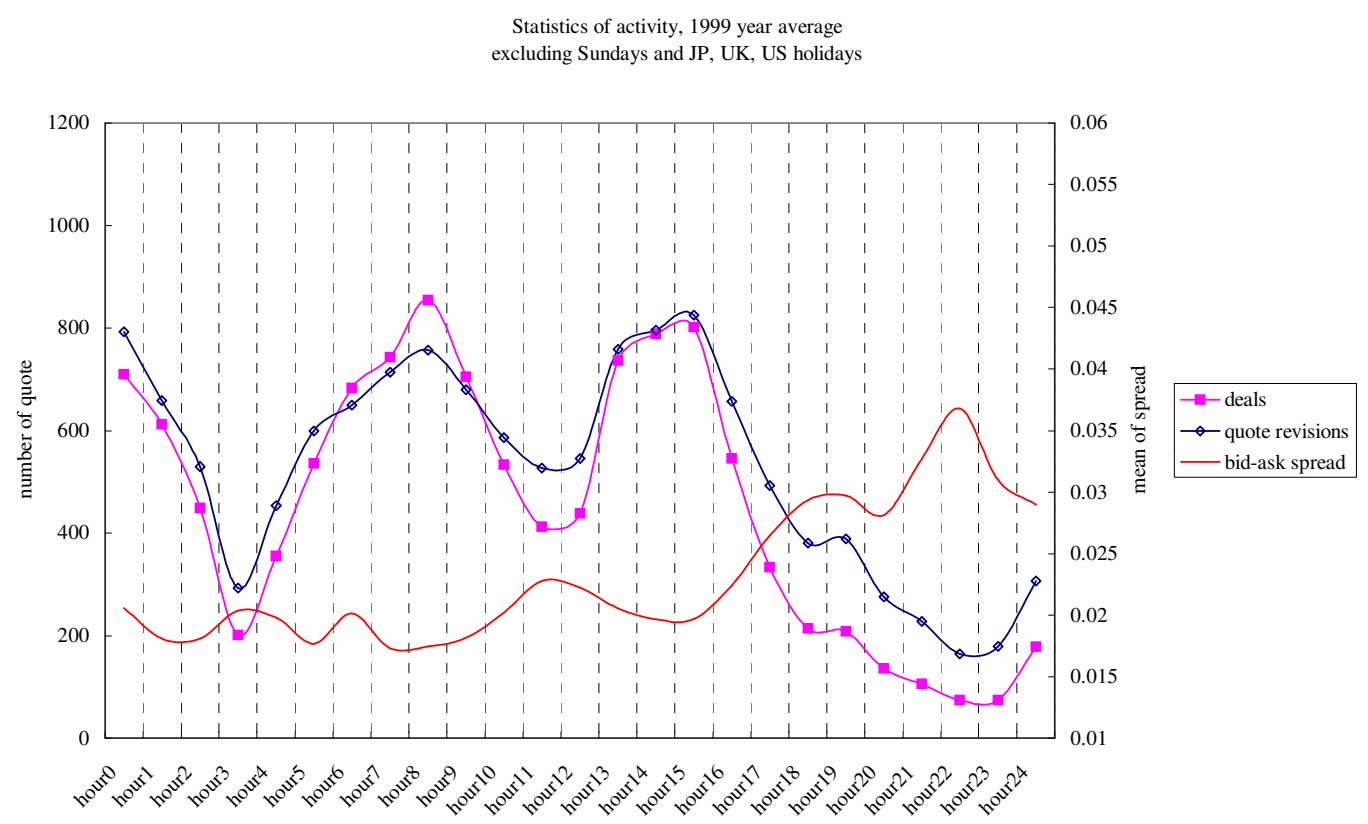

Figure 3-2: The year of 2000

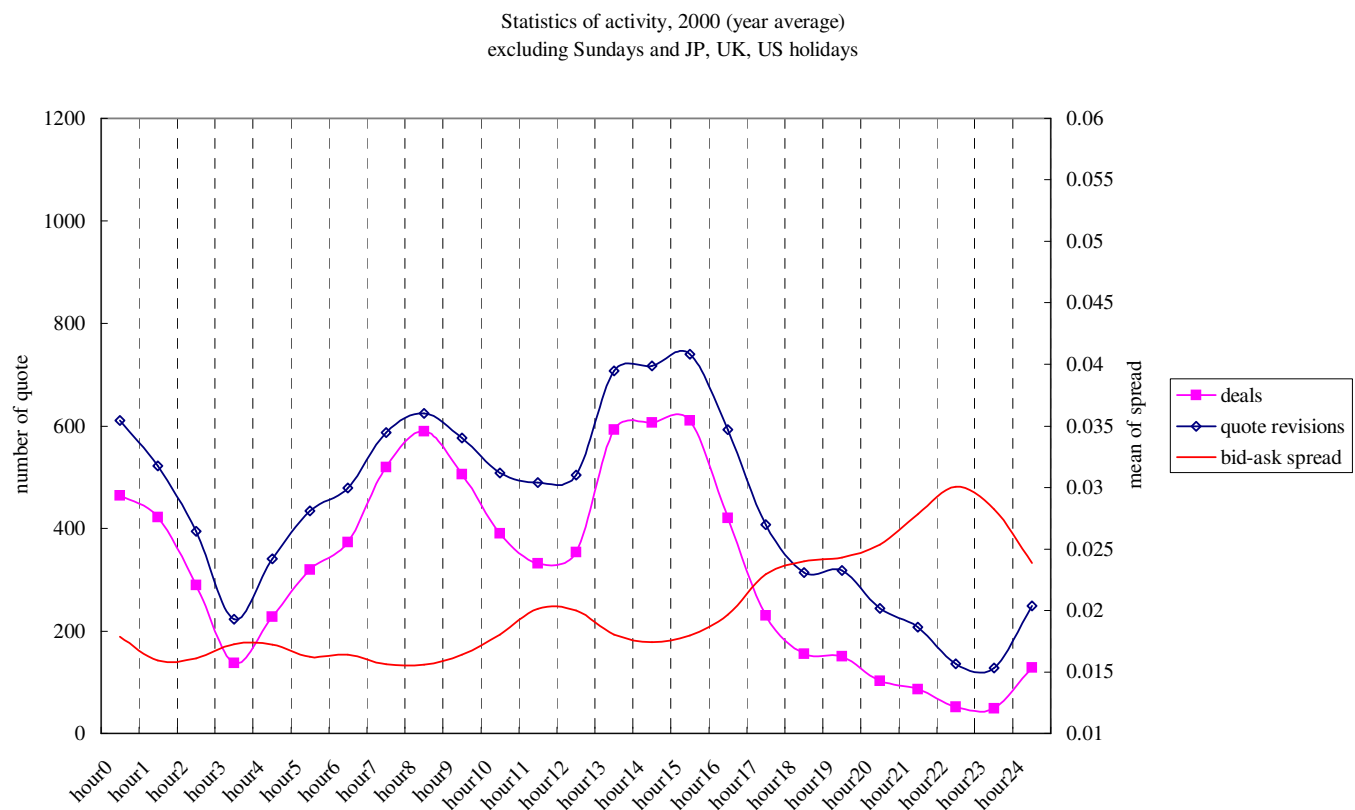


Figure 3-3: The year of 2001

Statistics of activity, 2001 year average excluding Sundays and JP, UK, US holidays

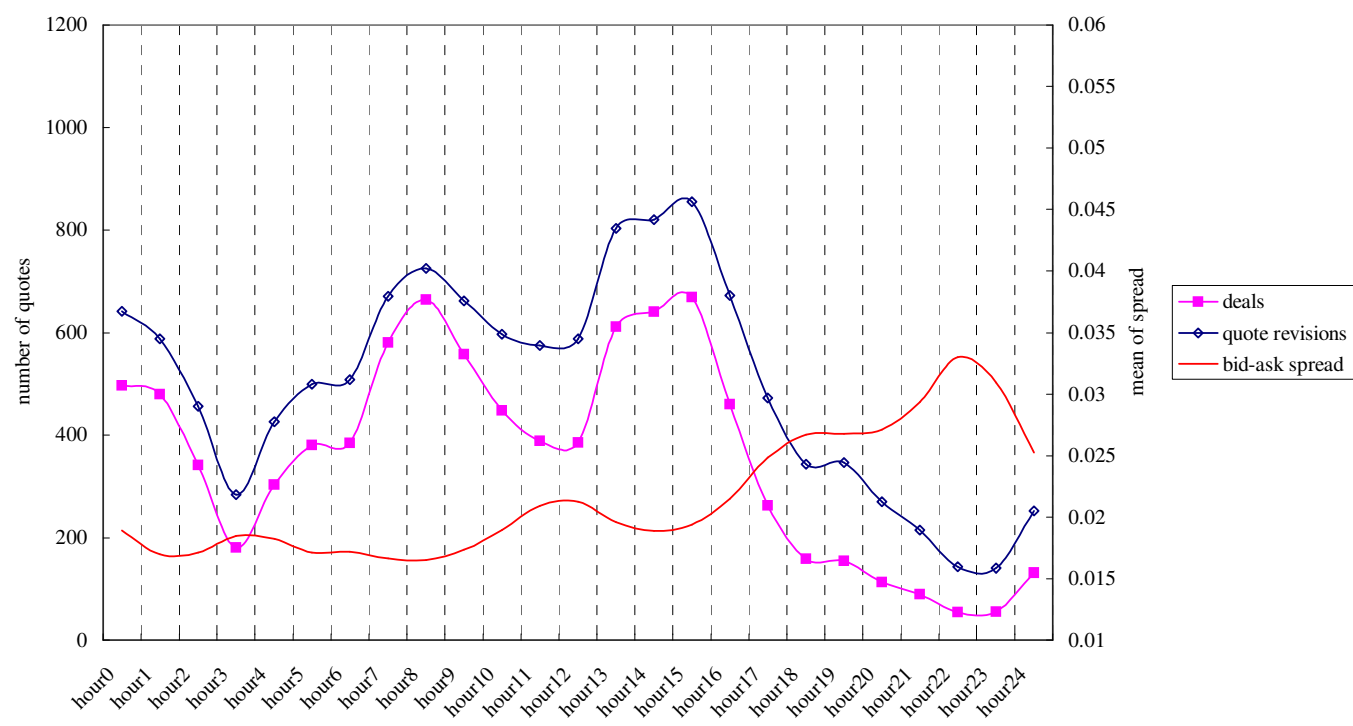


Figure 4-1: Monday, 2001

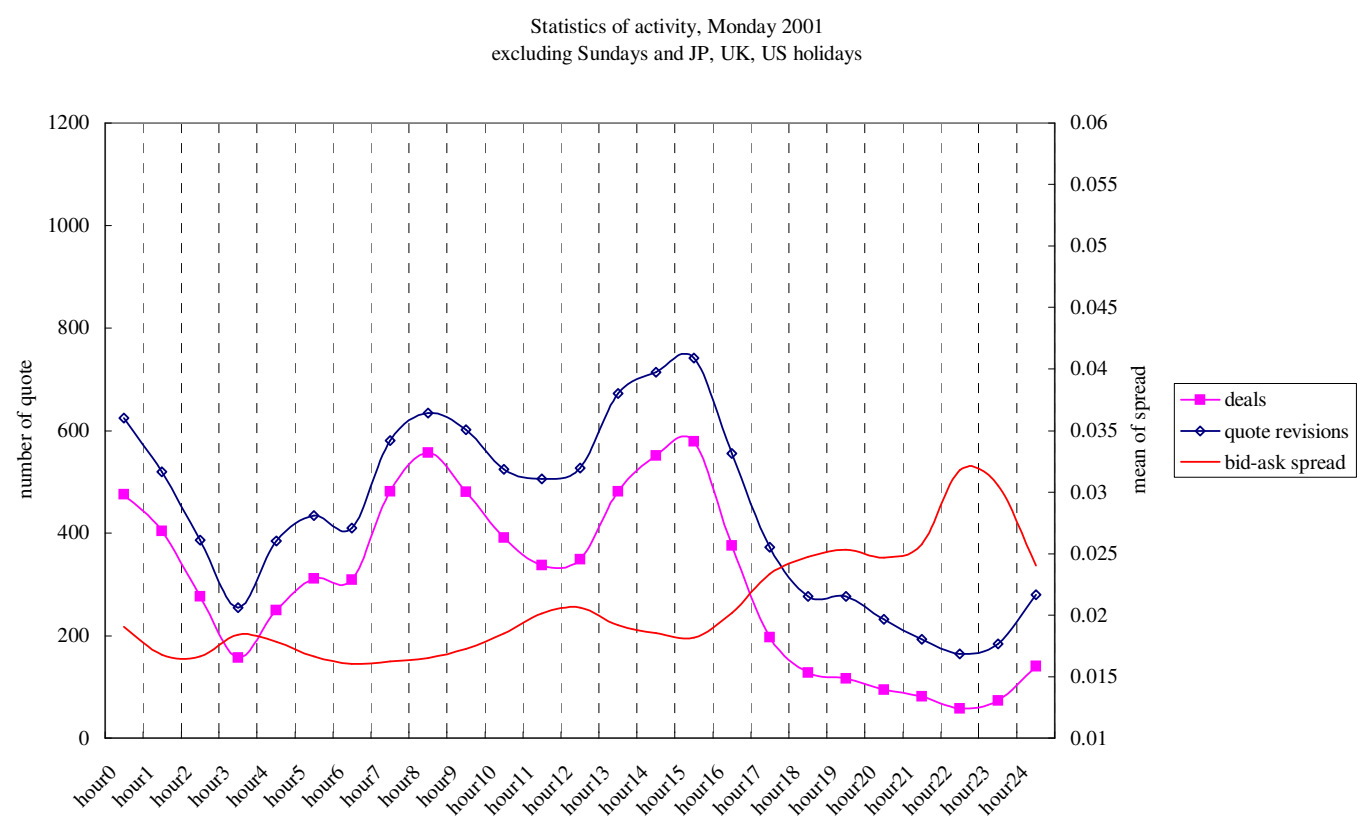

Figure 4-2: Tuesday, 2001

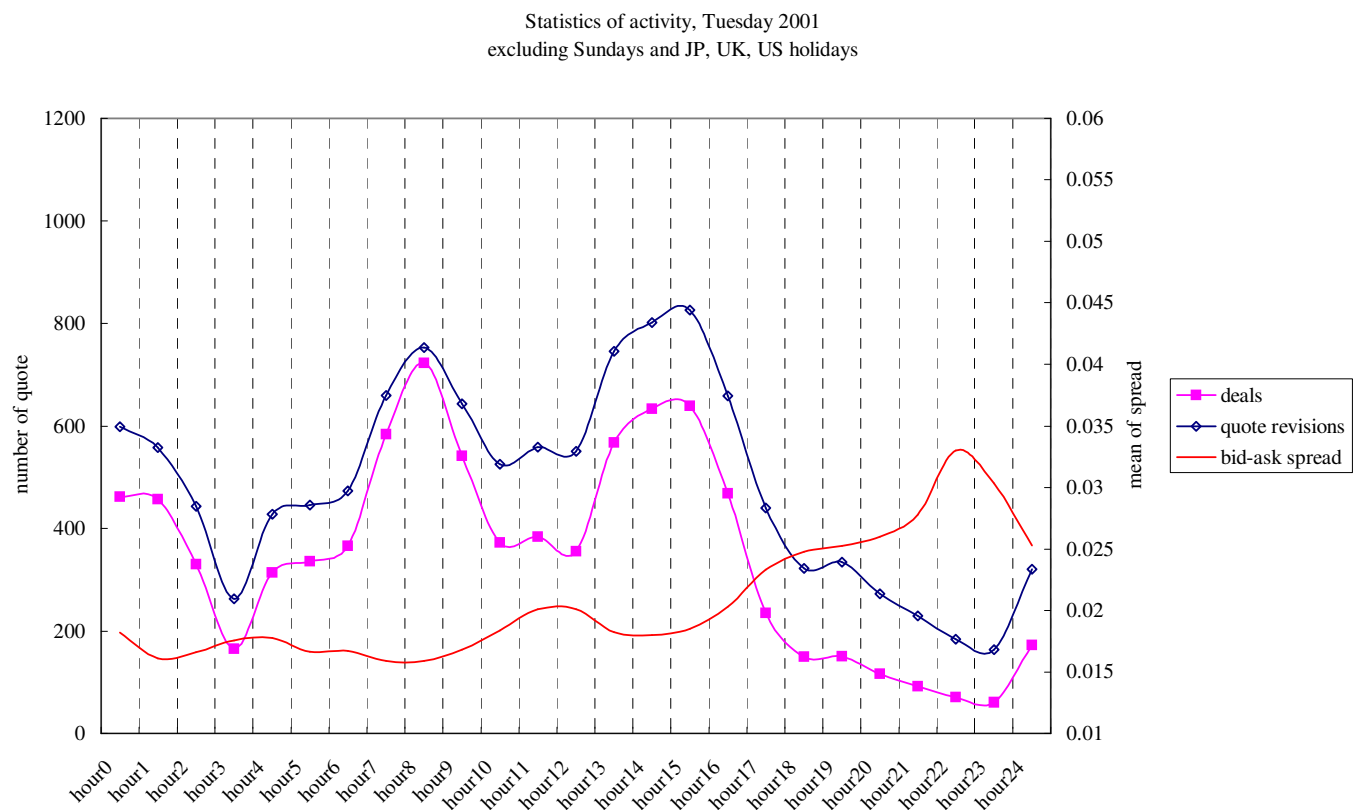


Figure 4-3: Wednesday, 2001

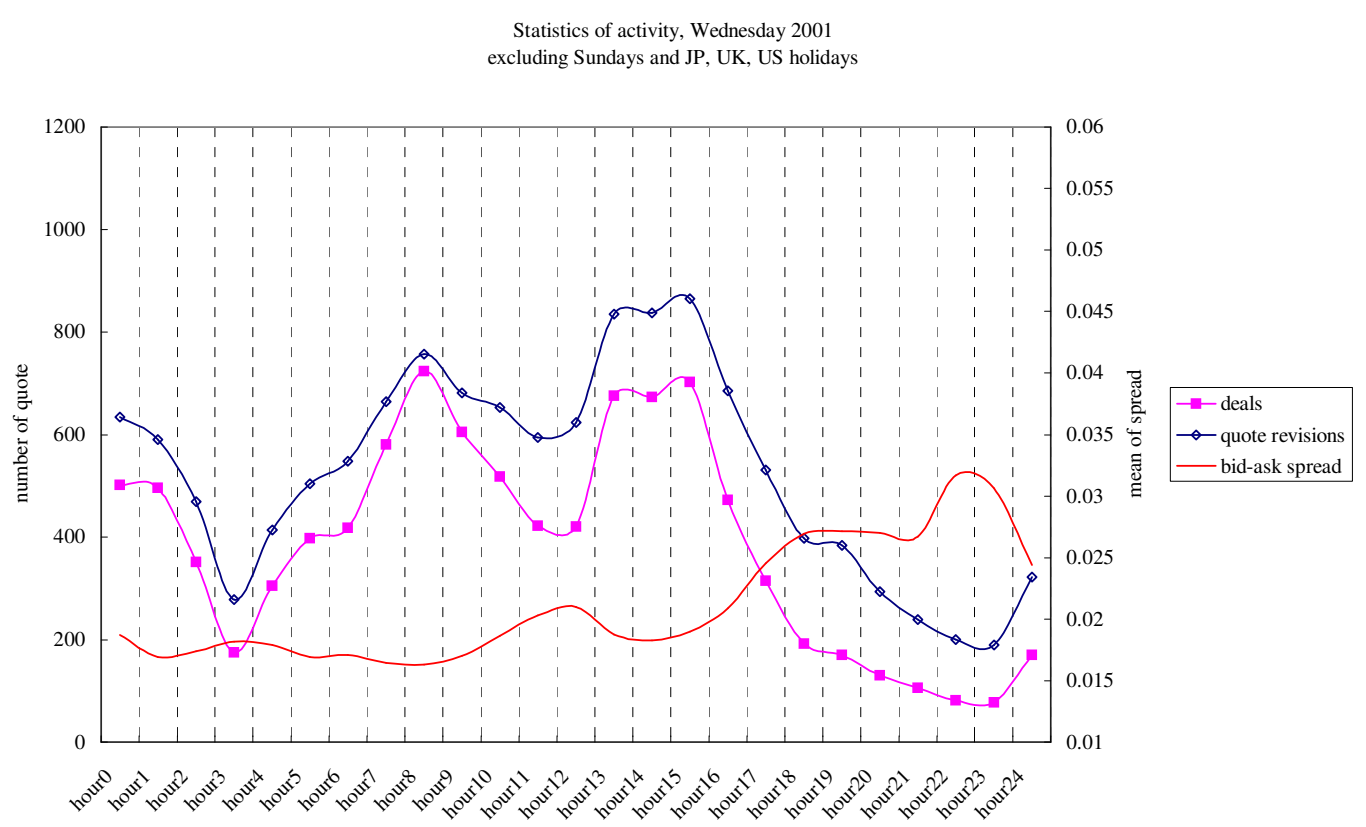

Figure 4-4: Thursday, 2001

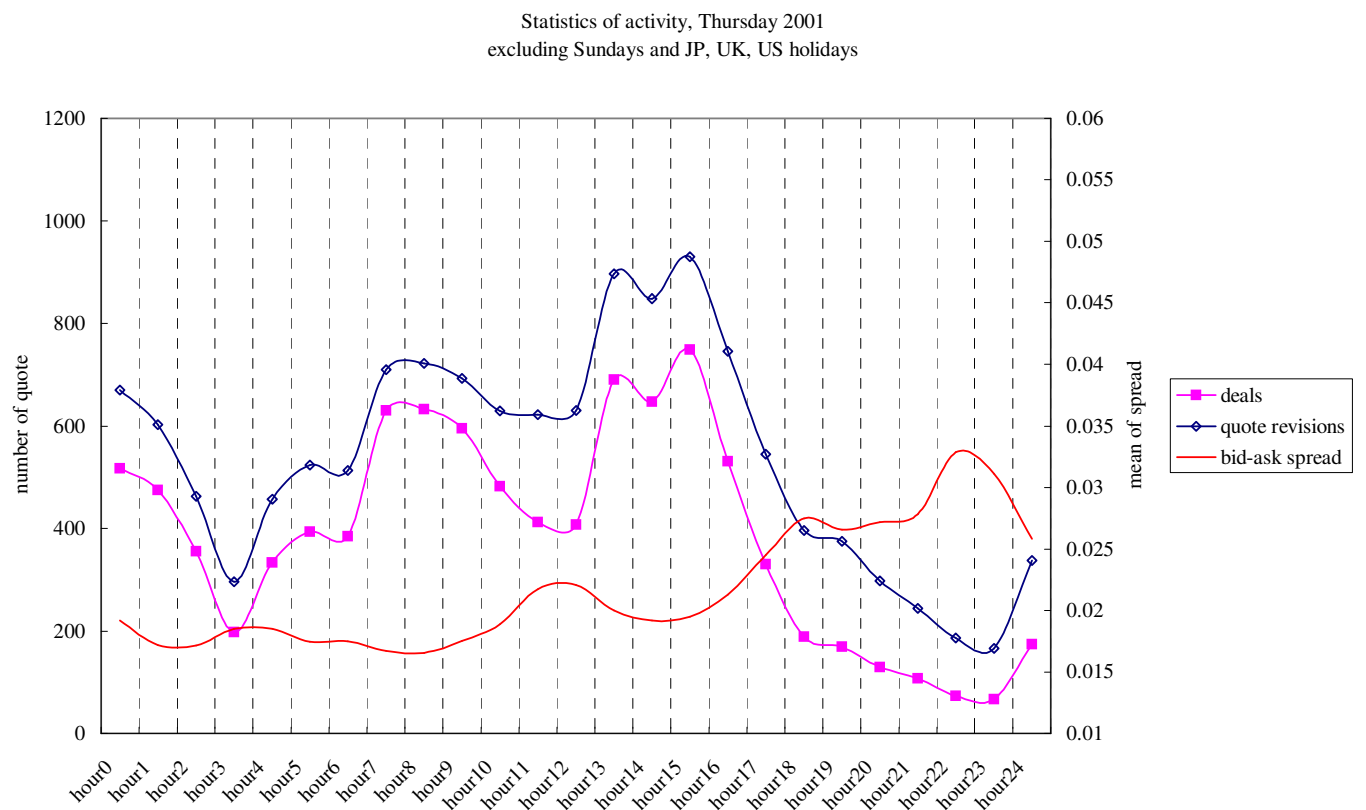


Figure 4-5: Friday, 2001

Statistics of activity, Friday 2001 excluding Sundays and JP, UK, US holidays

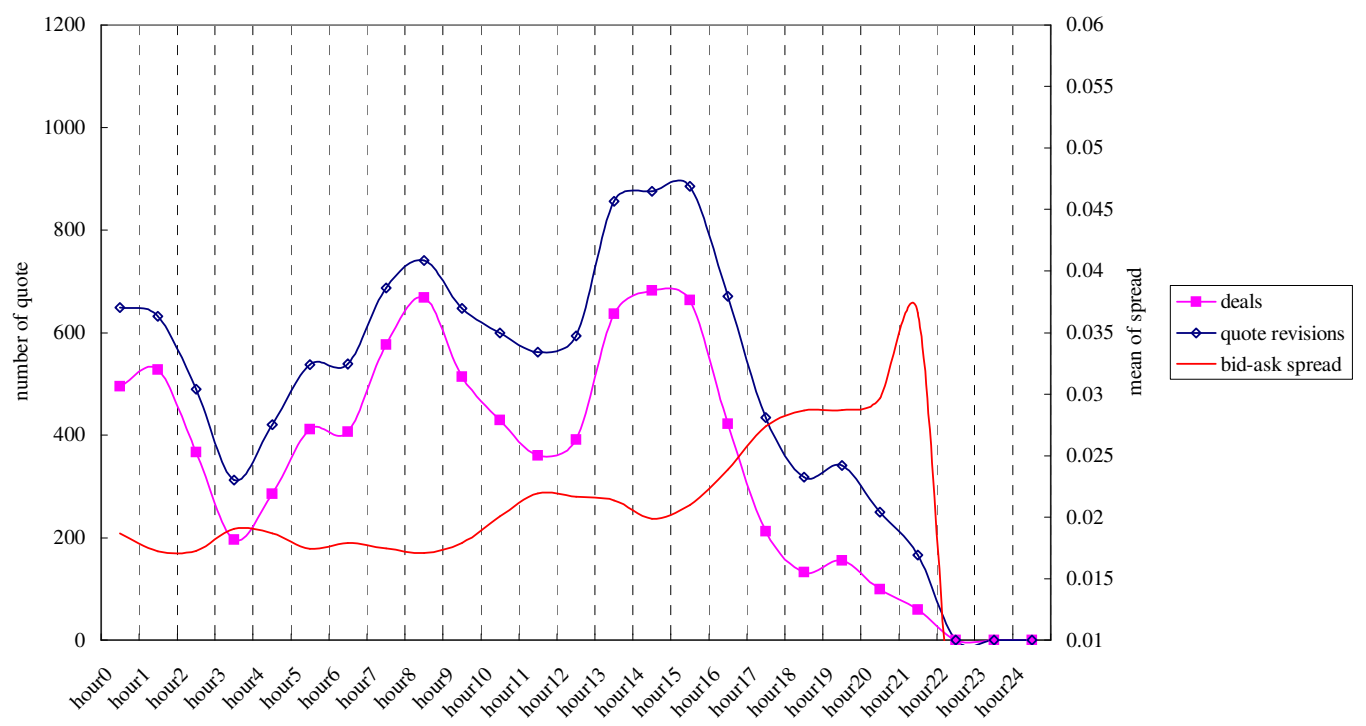


Figure 5-1 Monday opening (Hour 0), average of 1999

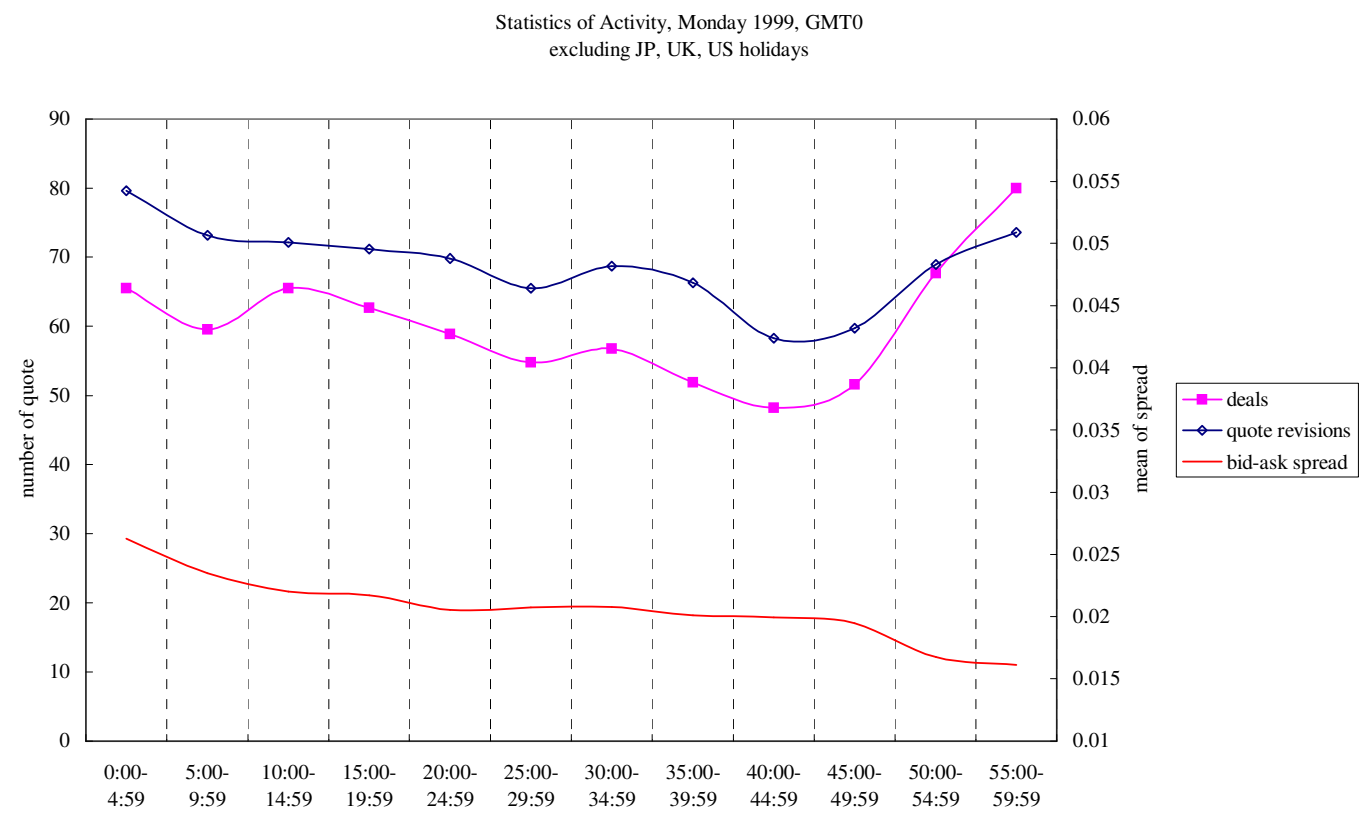

Figure 5-2 Monday opening (Hour 0), average of 2000

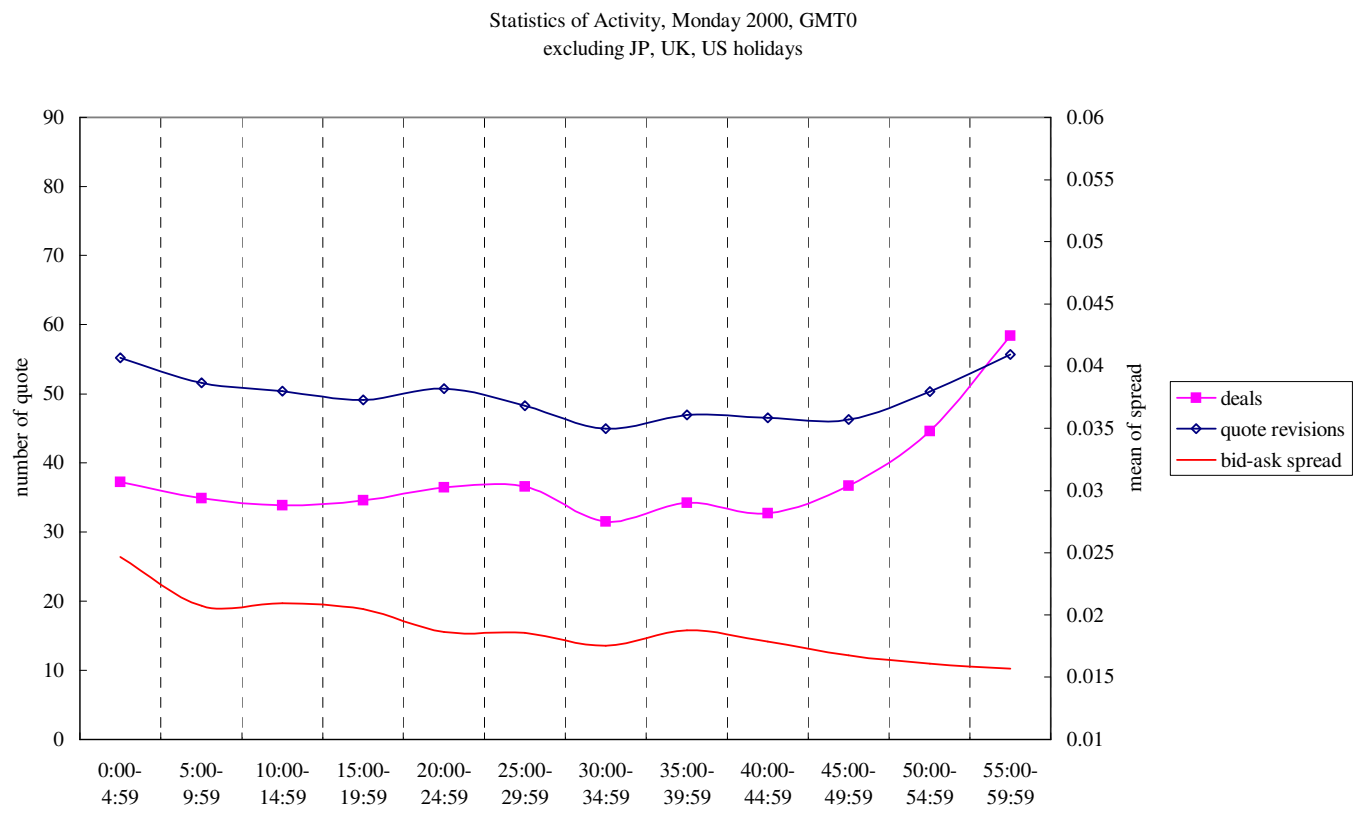


Figure 5-3 Monday opening (Hour 0), average of 2001

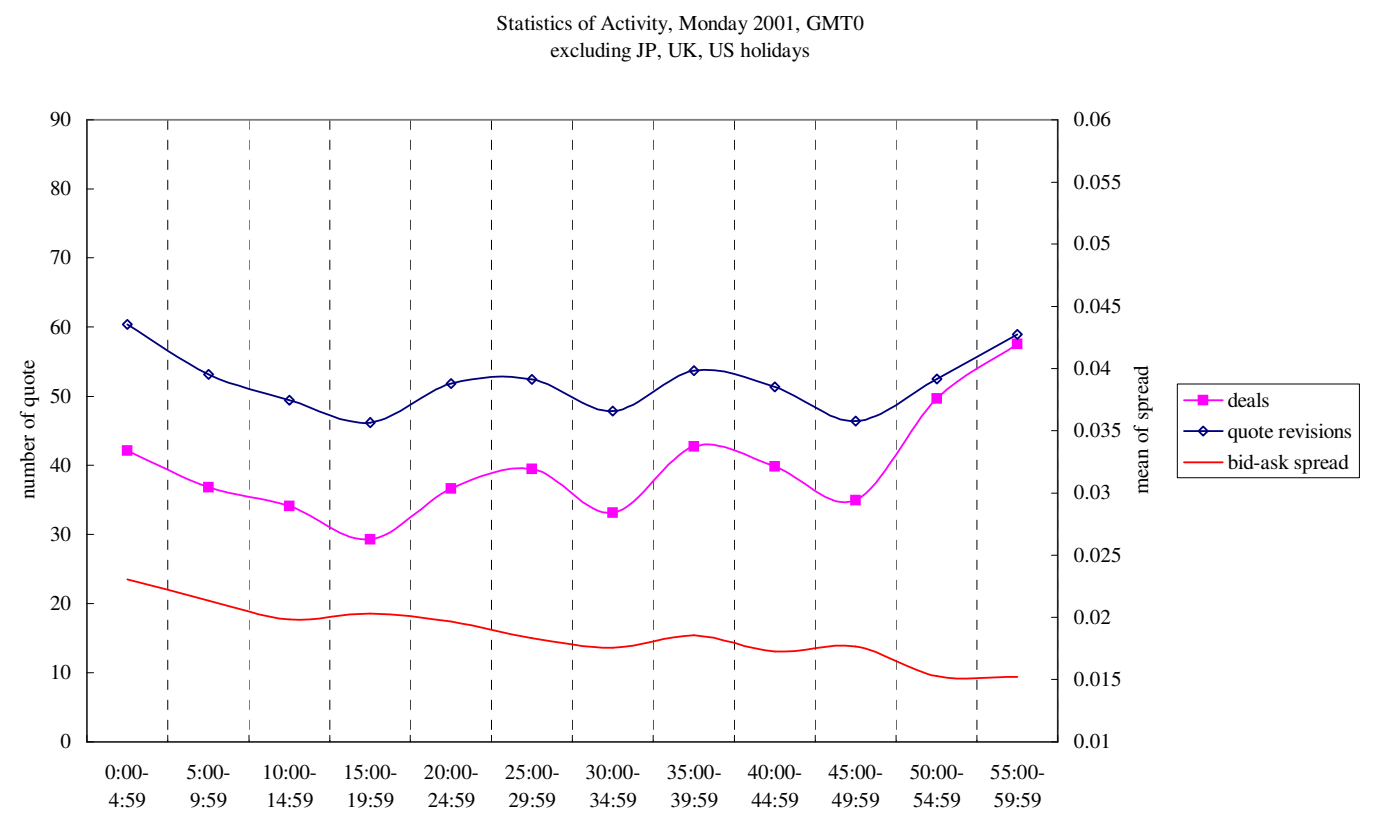

